Journal of the Electrochemical Society, Vol. 146, No. 12, 1999, pp. 4461-4472.

ISSN: 0013-4651

DOI: $10.1149 / 1.1392659$

http://www.electrochem.org/

http://www.ecsdl.org/getpdf/servlet/GetPDFServlet?filetype=pdf\&id=JESOAN000146000012004461000001\&idtyp e=cvips\&prog $=$ normal

(C) The Electrochemical Society, Inc. 1999. All rights reserved. Except as provided under U.S. copyright law, this work may not be reproduced, resold, distributed, or modified without the express permission of The Electrochemical Society (ECS). The archival version of this work was published in Journal of the Electrochemical Society, Vol. 146, No. 12, 1999, pp.4461-4472.

\title{
Influence of Dichromate Ions on Corrosion of Pure Aluminum and AA2024- T3 in NaCl Solution Studied by AFM Scratching
}

\author{
P. Schmutz and G. S. Frankel* \\ Fontana Corrosion Center, Department of Materials Science and Engineering, The Ohio State University, \\ Columbus, Ohio \\ * Electrochemical Society Active Member.
}

The localized corrosion of pure aluminum, AA2024-T3 alloy, and in particular the behavior of the intermetallic particles in AA2024-T3 were studied using a technique of scratching the surface with atomic force microscopy (AFM) tips. In situ AFM scratching provides information regarding the protectiveness of the surface film. Scratching of aluminum by rastering the surface with the AFM tip in contact mode in $0.5 \mathrm{M} \mathrm{NaCl}$ resulted in accelerated uniform dissolution in the rastered area. Slow pumping of the solution through the AFM cell during scratching, however, resulted in the development of sustained localized corrosion. Scratching in a stagnant $0.5 \mathrm{M}$ $\mathrm{NaCl}$ solution containing $10^{-4} \mathrm{M} \mathrm{Na} 2 \mathrm{Cr}_{2} \mathrm{O}_{7}$ also resulted in the development of large pits. For higher dichromate concentrations $(0.005$ and $0.05 \mathrm{M})$, neither accelerated dissolution nor pitting was observed, most probably because of the formation of harder chromium containing surface oxide. AFM scratching of AA2024-T3 in $0.01 \mathrm{M} \mathrm{NaCl}$ resulted in the immediate dissolution of the $\mathrm{Al}-\mathrm{Cu}-\mathrm{Mg}$ particles because of a destabilization of the surface film during light scratching. The addition of very dilute concentrations of dichromate $\left(10^{-4} \mathrm{M}\right)$ to $0.5 \mathrm{M} \mathrm{NaCl}$ completely suppressed the corrosion of the $\mathrm{Al}-\mathrm{Cu}-\mathrm{Mg}$ particles during AFM scratching, but breakdown in the matrix occurred in a similar fashion as for pure aluminum. The addition of $0.005 \mathrm{M}$ dichromate to $0.5 \mathrm{M} \mathrm{NaCl}$ again suppressed localized breakdown for low applied force during scratching, but pits formed at the $\mathrm{Al}-\mathrm{Cu}-\mathrm{Mg}$ particles at high forces. Higher dichromate concentration $(0.05 \mathrm{M})$ did not completely suppress the localized breakdown at Al-Cu$\mathrm{Mg}$ particles, but the amount and lateral spreading of the dissolution was much smaller.

In situ scratching has been used in the past to assess repassivation behavior by localized removal of the passive film. ${ }^{1-6}$ Other related techniques have also been used to create freshly bared areas on passive samples including breaking, ${ }^{7,8}$ guillotining, ${ }^{9-14}$ impingement with particles, ${ }^{15}$ and laser irradiation. ${ }^{16-18}$ These studies have provided considerable insight into the nature of passivity and the kinetics of repassivation. Most of the prior work studied current transients generated under potential control. Concerns regarding the influence of the capacitance of the nearby passive film on the measured current have been discussed. ${ }^{1,19-23}$

Pressure applied by an atomic force microscopy (AFM) tip on the surface of a sample during in situ contact mode rastering is a form of scratching on the microscale. Simultaneous imaging of the surface during scratching with the AFM tip provides direct information regarding the breakdown or repassivation processes. Guay et al. showed that the dissolution rate of pure aluminum thin films is locally enhanced during controlled AFM rastering in dilute chloride solutions. $^{24,25}$ The loss of material was followed by determining the average roughness as a function of time. A relation between the applied force and the decrease of roughness was observed. ${ }^{25}$ 
In a previous study, $\mathrm{AFM}$ scratching in $\mathrm{NaCl}$ solutions was used with high applied force to stimulate local depassivation events on commercially pure aluminum (AA1100) and near different inter-metallic particles in AA2024-T3. ${ }^{26}$ Rastering of AA1100 resulted in enhanced uniform dissolution, producing a flat-bottomed trench. The nominal dissolution rate increased with applied photodiode set-point or tip/sample interaction force. The behavior of AA2024-T3 depended on the exact location in the microstructure that was scratched. Scratching of $\mathrm{Al}-\mathrm{Cu}-\mathrm{Mg}$ intermetallic particles in chloride solution resulted in their immediate dissolution. In the absence of scratching, similar particles were found to be stable for a few hours and then dissolve. This behavior was attributed to the influence of unstable surface films that provided some protection when present but could be easily destabilized. In contrast, scratching of $\mathrm{Al}-\mathrm{Cu}-(\mathrm{Fe}, \mathrm{Mn})$ intermetallic particles in AA2024-T3 did not result in localized corrosion. However, evidence for inhomogeneities in these particles was presented, and some of them were observed to partially corrode.

AFM was also used in the previous study to characterize the Volta potential distribution on sections of AA2024-T3 by means of a technique called scanning Kelvin probe force microscopy (SKPFM). ${ }^{27}$ SKPFM values measured in air on a range of pure metals were correlated to open-circuit potential measurements made in solution just prior to the SKPFM measurements. The submicron resolution of SKPFM provided easy and clear visualization of the various intermetallic particles in AA2024-T3. The knowledge of the locations of the intermetallic particles enabled the development of a better understanding of how and exactly where breakdown occurs on this alloy. For instance, SKPFM was used to guide the AFM scratching experiments described.

In this study, in situ AFM scratching is used to investigate the mechanism of corrosion inhibition of $\mathrm{Al}$ alloys by chromates. Previous studies have shown that the amount of chromate required depends on the $\mathrm{NaCl}$ concentration and on the aspect of pitting corrosion under study. ${ }^{28-}$ ${ }^{30}$ The growth of large pits through $\mathrm{Al}$ foils up to $0.2 \mathrm{~mm}$ in thickness in $0.01 \mathrm{M} \mathrm{NaCl}$ was not affected unless $0.1 \mathrm{M} \mathrm{NaCrO}_{4}$ was added, a 10:1 ratio. ${ }^{28}$ The pitting potential of $\mathrm{Al}$ was found to increase only if the chromate:chloride ratio was about $1: 1 .^{29}$ Metastable pitting of Al was strongly reduced when the ratio was only $0.01,{ }^{30}$ so the amount of chromate needed to affect pitting seems to increase as the scale of the pits increases. The strong oxidizing power of chromates can also initiate pits at open-circuit potential (OCP) that would not form in a chromate-free chloride solution, but these pits are essentially metastable. ${ }^{31}$ Conventional scratching experiments have shown that active dissolution of AA7010 is strongly inhibited, even for a very small amount of chromate $(0.003 \mathrm{M}){ }^{32}$ The behavior of $\mathrm{Mg}$ is also of interest because of the high concentration of $\mathrm{Mg}$ in the $\mathrm{S}$ phase particles (Al-Cu-Mg) in AA2024-T3. The influence of chromate on the stabilization of the $\mathrm{Mg}(\mathrm{OH})_{2}$ surface layer on $\mathrm{Mg}$ and a strong passivating effect near the OCP have been reported. ${ }^{33,34}$

\section{Experimental}

Scratching experiments were performed in a fluid cell with a commercial AFM (Nanoscope IIIa, Digital Instruments) using commercially available Si tips. In situ contact mode rastering was performed for varying periods of time. The effect of tip pressure during in situ contact rastering was determined by changing the setpoint voltage on the photodetector sensor that monitors the cantilever deflection. Areas were rastered at set points ranging from 0.2 to $8 \mathrm{~V}$ The upper limit of setpoint voltage studied depended on the solution and type of sample. The 
effect of high-force rastering on the surface topography was determined by subsequently reducing the set point to $0.2 \mathrm{~V}$ and increasing the scanned area size. The results are discussed in terms of applied set point instead of tip pressure because the relation between the two is not straightforward and dependent on changes in tip shape that might occur during the experiment.

In some experiments solution was pumped through the AFM electrochemical cell from a reservoir at a rate of approximately $10 \mathrm{~mL} / \mathrm{h}$ using a peristaltic pump. The Digital Instruments cell had an inlet and outlet port to facilitate the solution flow. Electrochemical measurements made in the AFM cell were performed with a Radiometer PGP 201 potentiostat controlled by a computer. A platinum mesh counter electrode and standard calomel reference electrode (SCE) were used. The reference electrode was sealed in the pumping circuit about $5 \mathrm{~cm}$ downstream of the cell. The counter electrode was placed in the waste beaker. All the potentials are referred to the SCE electrode.

SKPFM was performed with the Nanoscope III AFM. The surface topography and Volta potential distribution were measured simultaneously on a line-by-line basis using metal-coated silicon tips that are electrically conducting. The SKPFM measurements were made in air and not in situ, although a correlation reported previously indicated that the SKPFM output provides a map of the practical nobility of the surface. ${ }^{27}$ The cantilevers were obtained from Digital Instruments and were coated with a thin layer of $\mathrm{Co}-40 \mathrm{Cr}$ or $\mathrm{Ni}$-Si. The Volta potential values are reported $v s$. the potential measured on a pure $\mathrm{Ni}$ sample that was used as a calibration standard. The topographic map obtained during the SKPFM measurement was performed in tapping mode with an amplitude of about $1 \mathrm{~V}$. A detailed description of the SKPFM technique can be found in a previous paper. ${ }^{27}$

A Philips Electronics model XL-30 scanning electron microscope with a field emission gun (FEG) was used to characterize some samples. It is equipped with an EDAX Corp. model DX-4 system for energy-dispersive spectroscopy (EDS) analysis and has a super ultrathin window for higher sensitivity. An accelerating voltage of $10 \mathrm{kV}$ was used for both secondary electron imaging and EDS. Auger measurements were made with a PHI-Perken Elmer 680 Scanning Auger Nanoprobe system which also has a field-emission gun. A 10 kV, 1 nA electronbeam was used for the measurements, allowing a lateral resolution of approximately $30 \mathrm{~nm}$. Depth profiling was performed by sputtering a $2 \times 2 \mathrm{~mm}$ area with $1 \mathrm{kV}$ Ar ions at a current of $0.5 \mu \mathrm{A}$. The sputtering rate of a $100 \mathrm{~nm} \mathrm{SiO} 2 / \mathrm{Si}$ reference sample using the given parameters was $2.85 \mathrm{~nm} / \mathrm{min}$. Intensities were corrected for the relative sensitivity factors to give an approximate composition of the surface.

Two different polishing procedures were used for pure (99.99\%) Al samples: $(i)$ wet grinding to 1200 grit $\mathrm{SiC}$ paper and then polishing in an alkaline colloidal silica slurry (MasterMet, Buehler) and (ii) wet grinding to 1200 grit SiC paper, then polishing with 6 and 1 $\mu \mathrm{m}$ diamond paste in an alcohol-based slurry (Blue Lube, Struers), followed by polishing in an alkaline colloidal silica slurry.

The AA2024-T3 samples (nominal composition 4.9-3.8\% Cu, 1.8-1.2\% $\mathrm{Mg}, 0.9-0.3 \%$ $\mathrm{Mn}, 0.5 \% \mathrm{Fe}$ and $\mathrm{Si}, 0.25 \% \mathrm{Zn}, 0.1 \% \mathrm{Cr}, 0.05 \mathrm{Ti}$, balance $\mathrm{Al}$ ) were wet ground through 1200 grit $\mathrm{SiC}$ paper, and then polished to $1 \mu \mathrm{m}$ in a nonaqueous slurry (Blue Lube from Struers) to minimize corrosion. They were then cleaned in ethyl alcohol.

Pure Mg samples (99.99\%) were also tested. The pure $\mathrm{Mg}$ was polished by the same method as for pure Al described previously, wet grinding in 1200 grit $\mathrm{SiC}$ and then polishing in an alkaline colloidal silica slurry. 


\section{Results and Discussion}

AFM scratching of pure Al.-The first series of experiments is related to scratching of pure aluminum samples. Figure 1 shows the surface of a pure aluminum sample $(99.99 \%)$ rastered with the AFM tip in $0.5 \mathrm{M} \mathrm{NaCl}$ solution. The square $15 \times 15 \mu \mathrm{m}$ central area was rastered at higher set point, resulting in accelerated dissolution in this region. A uniform smoothbottom trenching can be obtained this way, Fig. 1b. Detailed description of this phenomenon, especially the effective dissolution rate and influence of applied set point, has been published elsewhere for AA1100 samples. ${ }^{26}$ It is assumed that the scratching of the surface by the $\mathrm{Si}$ cantilever causes depassivation, followed by limited dissolution and repassivation. Since Al probably does not exist in the unfilmed state in this solution, it may be considered that the scratching simply causes accelerated dissolution of Al through a thin oxide. The 99.99\% Al sample was found to behave identically to AA1100 in AFM scratching experiments. It is interesting to note that scratching of pure $\mathrm{Al}$ in $0.5 \mathrm{M} \mathrm{NaCl}$ did not result in the formation of pits even though $\mathrm{Al}$ might not be expected to repassivate spontaneously in this solution.

An explanation for this behavior can be given based on the concept that a critical current density is necessary to sustain depassivation and result in a stable pit. ${ }^{35}$ For high rates of anodic dissolution at open circuit, such as is the case for freshly depassivated Al, the overall reaction is often limited by the rate of the cathodic reaction. Al dissolution initiated where the passive film was removed by the scratching action of the AFM tip. The rate of Al dissolution at the instant of depassivation can be very high. The current density in the first microseconds of a thin-film breaking experiment has been found to be on the order of hundreds of amperes per square centimeter. ${ }^{7,8}$ In order for the passive film breakdown to result in stable pitting, the rate of dissolution must be sustained at current densities on the order of amperes per square centimeter over the first fractions of a second following breakdown. ${ }^{35}$ If the current density is not maintained at values above a critical level, thereby maintaining the severity of the local environment, the region of local attack will repassivate. ${ }^{36}$ At open circuit, the high dissolution rate must be accompanied by an equally high rate of cathodic reaction, which in aerated $0.5 \mathrm{M}$ $\mathrm{NaCl}$ is primarily oxygen reduction. Since the volume of electrolyte in the AFM cell was rather small (about $0.1 \mathrm{~mL}$ ) and the cell was sealed, the supply of oxygen was finite and it quickly dropped to a level insufficient to maintain the required rate of anodic reaction. The result of continual film breakdown, accelerated dissolution, and repassivation was the formation of a uniform trough. This is essentially erosion corrosion. 

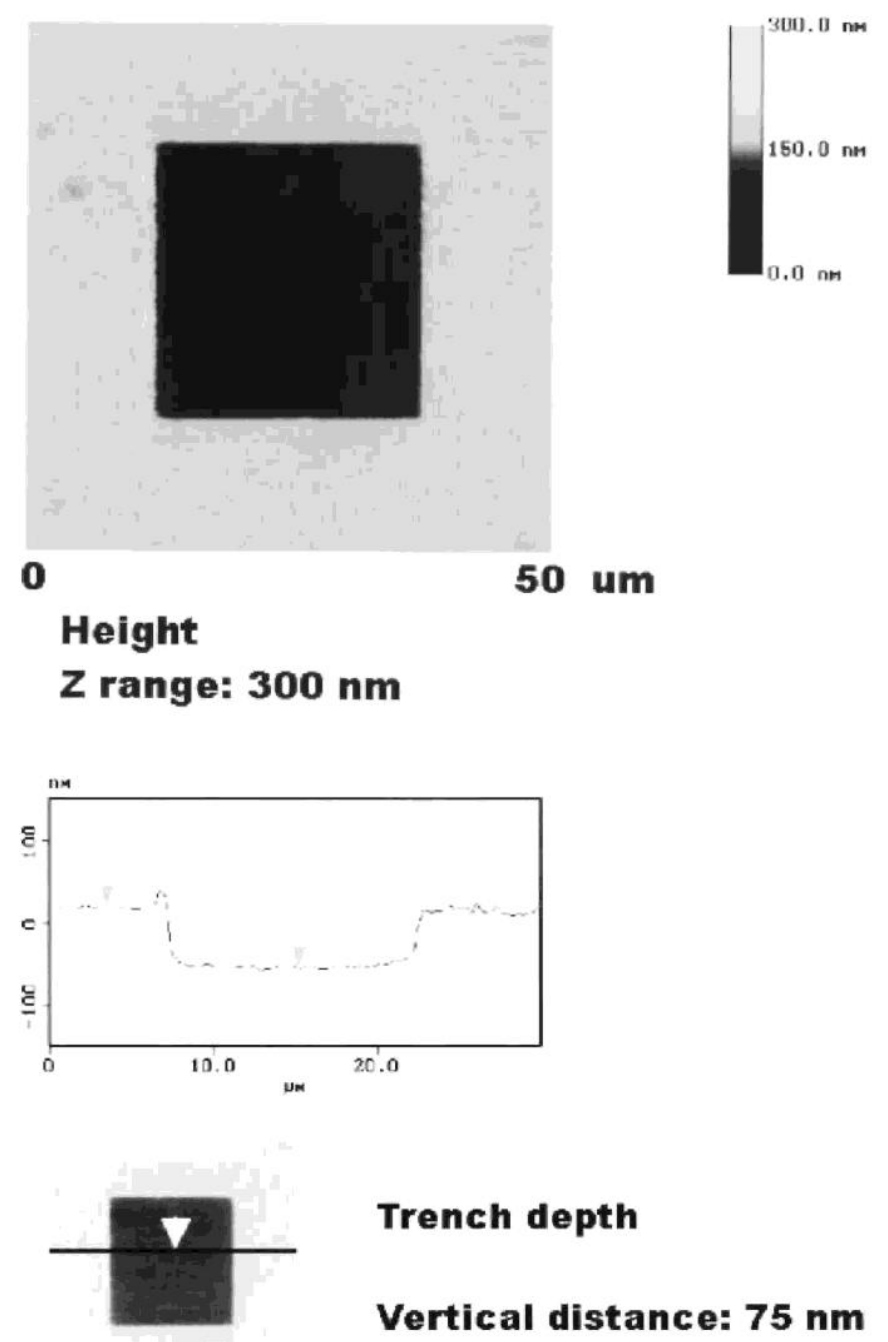

Figure 1. (a, top) In situ topographic map of a $15 \mu \mathrm{m}$ square hole in Al $99.99 \%$ obtained by contact-mode scratching of the AFM tip in $0.5 \mathrm{M} \mathrm{NaCl}$. Set point increased up to $5 \mathrm{~V}$ in steps of $1 \mathrm{~V} / \mathrm{h}$. (b, bottom) Topography line-scan of the smooth-bottomed trench.

This interpretation is supported by an experiment in which the $0.5 \mathrm{M} \mathrm{NaCl}$ solution was continually pumped through the AFM cell during scratching. Instead of accelerated uniform corrosion resulting in the formation of a flat-bottomed trough, scratching with solution flow at open circuit tended to result in pitting, Fig. 2. The line scan shown in Fig. 2a shows that the pit was about $3.5 \mu \mathrm{m}$ in depth. The flow of the chloride solution from a reservoir that was exposed to air resulted in maintenance of the dissolved oxygen concentration at a level sufficient to sustain pitting. Another way of viewing this situation is that the higher cathodic reaction rate polarizes the electrode to a potential above the repassivation potential. Although the flow rate was very slow, it is also possible that enhanced convection reduced the diffusion layer thickness, thereby increasing the transport of oxygen to the surface. Changes in $\mathrm{pH}$ in the small AFM cell might also be important. If so, solution flow would reduce this effect. 

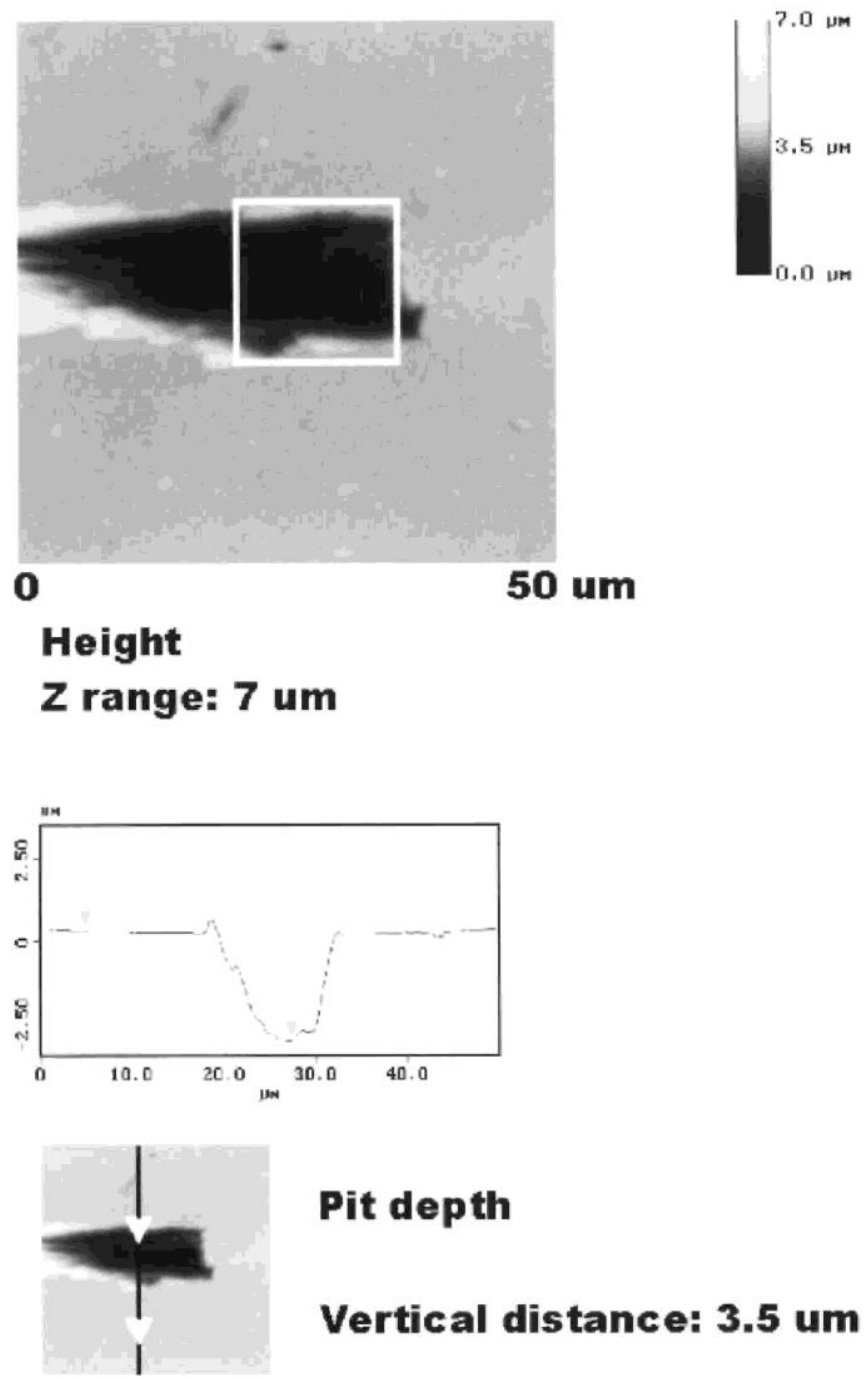

Figure 2. In situ topographic map of a pit in Al $99.99 \%$ obtained by contact-mode scratching at a set point of $0.5 \mathrm{~V}$ in $0.5 \mathrm{M} \mathrm{NaCl}$ with solution flow at about $10 \mathrm{~mL} / \mathrm{h}$. The box indicates the scratched area.

It should be noted that copious hydrogen evolution is associated with the initiation of pits in Al. The hydrogen bubbles emanating from a pit interfere with the AFM tip and prevent accurate imaging. Therefore, when a pit initiated during a scratching experiment, the set point was decreased and the tip was withdrawn from the sample. When the pit stopped growing, as evidenced by a cessation of hydrogen bubbles evolving in the video monitor that is attached to the AFM, the surface was imaged again at a low set point of $0.2 \mathrm{~V}$. Therefore, all images of pits in this paper are of pits that had stopped growing. In Fig. 2, the dissolution is seen to extend beyond the scratched region on one side only. The flow direction was from the top of the image, and the scratching was in both horizontal directions, so the reason for the directionality of attack is unknown. 
Further evidence for the influence of the cathodic reactant on the stabilization of localized corrosion is obtained by monitoring the sample potential during the scratching experiment, Fig. 3. In the absence of flow, the potential quickly dropped to values comparable to those obtained in a bulk deaerated solution. Scratching was started almost at the beginning of the experiment and continued with progressively increasing set point values resulting in trenching of the sample. With a flow of about $10 \mathrm{~mL} / \mathrm{h}$, the potential was higher. Pitting initiated when the set point was increased to $0.5 \mathrm{~V}$, which was early in the experiment. At that time the scratching was stopped, and the pit stopped growing. Figure 2 shows the pit at this point. Afterward, the potential was simply monitored with time, and no scratching or imaging was performed. The potential remained at a high value that was almost constant for a few hours because oxygen was continuously provided to the sample by the flow. In a large cell $(100 \mathrm{~mL})$ containing solution exposed to air with the sample pressed against an O-ring on the bottom, the potential increased with time. In this case, the potential change may have resulted from changes in solution chemistry at the sample surface, which were possible because of the stagnant conditions. This cell was open to air, so continuous supply of oxygen was also present.

Pumping of deaerated solution through the AFM cell resulted in behavior similar to that observed in the stagnant AFM cell. The corrosion potential was low, and scratching also resulted in a smooth-bottomed trench. These observations clearly show the importance of the cathodic reaction in the stabilization of localized corrosion at open circuit.

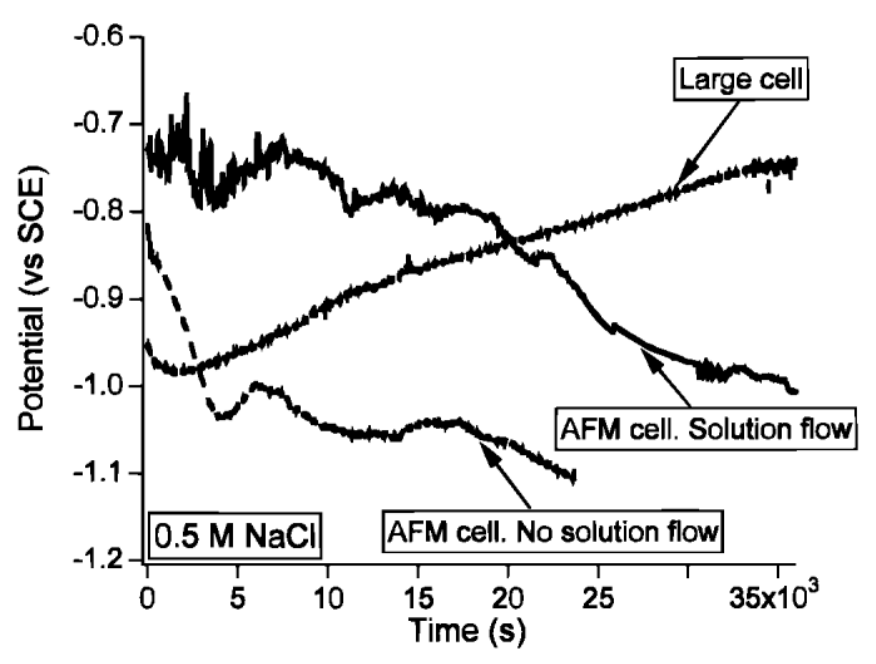

Figure 3. Evolution of OCP with time for different experimental conditions.

The polishing procedure for the Al sample and the resultant condition of the surface also proved to have a large influence on the behavior upon scratching and on the measured corrosion potential. All experiments described so far were on samples polished with colloidal silica. Figure 4 shows the potential during $\mathrm{AFM}$ scratching in $0.5 \mathrm{M} \mathrm{NaCl}$ with solution flow for samples polished by three different procedures. Colloidal silica polishing resulted in a high potential of around $-730 \mathrm{mV} \mathrm{SCE}$ (Fig. 4, curve a), and localized corrosion occurred upon scratching at a force set point of $0.5 \mathrm{~V}$. During the 4000 s shown in Fig. 4, the tip was engaged and a scan was made at $0.2 \mathrm{~V}$ set point, and pitting initiated during a second scan at $0.5 \mathrm{~V}$ The measured 
corrosion potential was not influenced by the scratching, either before, during, or after pit formation. As shown later, the pitting potential measured by potentiodynamic polarization is very close to the potential of this sample. It is possible that pitting at locations distant from the rastered area controlled the sample potential.

Adding an intermediate polishing step with diamond paste resulted in a much lower OCP that started at -1 V SCE and gradually decreased further (Fig. 4, curve c). The reason for the effect of the diamond polishing step is not yet clear, as the final polishing step was still colloidal silica. During the $4000 \mathrm{~s}$ shown in Fig. 4, the tip was engaged and a scan was made at $0.2 \mathrm{~V}$ set point, followed by repetitive rastering at $0.5 \mathrm{~V}$. The experiment then continued for an extended period at higher set points. For this polishing procedure, no localized breakdown could be achieved during scratching with solution flow, even for set points as high as $5 \mathrm{~V}$. A trenching behavior was observed, similar to that found for the colloidal silica polished sample in the absence of solution flow. As for the sample polished without diamond paste, the scratching had no effect on the measured potential.

Allowing the sample to sit in laboratory air for $12 \mathrm{~h}$ after polishing with the diamond paste step and the final colloidal silica step resulted in an intermediate corrosion potential (Fig. 4, curve b). For this type of sample, an interesting phenomenon was observed. A potential increase of around $100 \mathrm{mV}$ was seen when the AFM tip touched the surface during the engagement procedure (point 1 on Fig. 4, curve b). The potential then immediately decreased even though the tip was in contact with the surface. Upon starting the rastering of a larger $15 \times 15 \mu \mathrm{m}$ area at a set point of $0.2 \mathrm{~V}$, the potential increased again by around $150 \mathrm{mV}$ (point 2 on Fig. 4, curve b). No localized corrosion occurred during scratching at a set point of $0.2 \mathrm{~V}$. Further increase of the set point voltage to $0.5 \mathrm{~V}$ resulted in a much larger increase in potential (point 3 on Fig. 4, curve b). At that point the potential was similar to that for the samples polished with colloidal silica, around $-700 \mathrm{mV}$ SCE. Reaching this high corrosion potential did not systematically result in

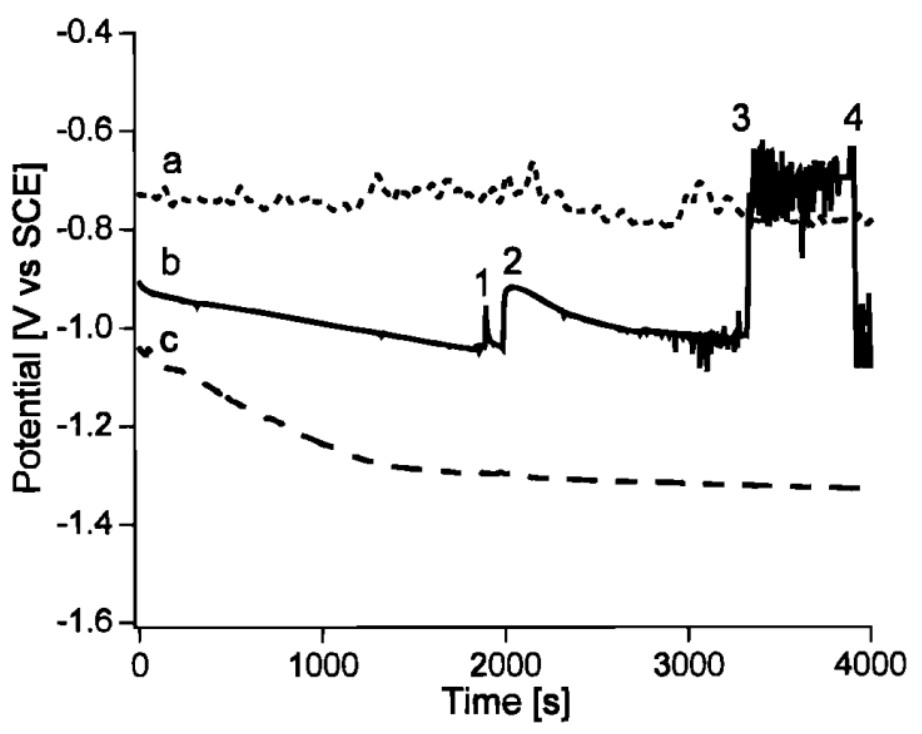

Figure 4. Evolution of OCP with time for different polishing procedures. 
pitting for these samples. The particular sample whose potential is given in curve b in Fig. 4 did not pit, but others did. Recall that the samples polished with colloidal silica pitted at a set point of $0.5 \mathrm{~V}$. As soon as the set point was decreased to $0.2 \mathrm{~V}$, the potential decreased again (point 4 on Fig. 4, curve b). Subsequent increase of the set point to $0.5 \mathrm{~V}$ on different areas resulted again in the same potential increase as observed in curve b in Fig. 4. These observations of the effects of surface finish on potential and scratching behavior were reproducibly observed on replicate samples.

Upon engaging the tip onto the surface, a contact between the Si tip and the sample is established. The above-mentioned example indicates that under certain circumstances (curve b), this galvanic contact influenced the corrosion potential measured by a remote reference electrode. However, this was not always the case, as the potential measured for other conditions was unaffected by the scratching. Differences in the oxide on the sample surface may account for this variability in the tip/sample galvanic coupling.

The influence of applied potential was also studied by potentiodynamic scanning during scratching. Samples polished with the diamond paste step were used in this experiment because they have a low OCP and do not pit at open circuit. They were immersed in $0.5 \mathrm{M} \mathrm{NaCl}$ solution for $1 \mathrm{~h}$ before the simultaneous initiation of scratching and potentiodynamic polarization from open circuit in the anodic direction at $0.5 \mathrm{mV} / \mathrm{s}$. Solution was continuously pumped at a rate of about $10 \mathrm{~mL} / \mathrm{h}$ before and during the experiments. Polarization curves in the AFM cell during rastering at a force set point of 0.5 and $3 \mathrm{~V}$ were recorded as well as for an unscratched sample in a large electrochemical cell filled with $100 \mathrm{~mL}$ of solution. Figure 5a shows that the current density at potentials above the pitting potential in the AFM electrochemical cell is much smaller than in the large cell. The solution resistance associated with the electrode configuration of the AFM cell was found to be about $10^{4} \Omega$ using electrochemical impedance spectroscopy. Correction of the data after initiation of pitting for the ohmic potential drop in the AFM cell using this solution resistance accounts almost exactly for the difference in the data from the two cells.

In the large cell, the OCP increased with time during the initial $1 \mathrm{~h}$ of immersion time, resulting in a value much higher than that found in the sample in the AFM cell. This potential increase with time in the large cell was reproducibly observed. There is also a certain spread in the potential measured in the AFM cell. Neither of these observations are explained at this point.

Figure $5 \mathrm{~b}$ shows an enlargement of the region near the pitting potential. The pitting potential, where the current increased rapidly, was very reproducible $( \pm 10 \mathrm{mV})$. It is interesting that the pitting potentials in the large cell and in the AFM cell with a rastering set point of $0.5 \mathrm{~V}$ are similar, around $-0.74 \mathrm{~V}$ SCE. For scratching at this low set point, pitting did not occur in the rastered area. The CCD camera mounted on the AFM system allowed visual observation of the surface during the experiment, and the location of the breakdown was obvious owing to the evolution of hydrogen bubbles described previously. Recall that samples prepared without the diamond-polishing step pitted in the rastered area during scratching at $0.5 \mathrm{~V}$ set point and at the OCP, which was about $-0.73 \mathrm{~V}$ SCE. The similarity in pitting potential for the large cell and the lightly scratched sample is related to the fact that the scratched sample pitted at a location away from the scratched area. For the higher force set point of $3 \mathrm{~V}$, pitting did initiate in the rastered area. The pitting potential value was lower by around $30 \mathrm{mV}$ in this case. During the potentiodynamic scratching experiments the pits grew to a size that was deeper than could be imaged by AFM. 
Effect of dichromate on $\mathrm{Al}$ scratching.-AFM scratching experiments were also performed on pure $\mathrm{Al}$ in dichromate-containing solution in the absence of solution flow An area was rastered for $1 \mathrm{~h}$ at different set points, starting at $0.2 \mathrm{~V}$ and incrementally increasing to higher values. After each $1 \mathrm{~h}$ treatment, the surface was imaged at the low set point of $0.2 \mathrm{~V}$. Figure 6 shows the surface after rastering at a set point of $1 \mathrm{~V}$ in a $0.5 \mathrm{M} \mathrm{NaCl}+10^{-4} \mathrm{M}$ $\mathrm{Na}_{2} \mathrm{Cr}_{2} \mathrm{O}_{7}$. Localized breakdown of the surface occurred, resulting in the formation of a deep pit. The pit shape was irregular and not exactly coincident with the rastered area. The linescan shown in Fig. $6 \mathrm{~b}$ indicates that the pit was over $1 \mu \mathrm{m}$ deep.

The observation of pitting during scratching of $\mathrm{Al}$ in chloride solution containing dilute dichromate is in stark contrast to the smooth-bottomed trench that formed in $0.5 \mathrm{M} \mathrm{NaCl}$ solution. Dichromate ions are usually incorporated in coatings or added to solutions to increase the corrosion resistance of the surface. It is therefore somewhat surprising that the presence of dichromate caused localized corrosion to occur. However, chromate is also an oxidizing agent. In this case the dichromate ions acted as an oxidizer and not a corrosion inhibitor, as the corrosion was even worse than in pure $0.5 \mathrm{M} \mathrm{NaCl}$. Dichromate additions to chloride solutions have also been found to enhance the formation of pits in Al thin films at open circuit. ${ }^{31}$ Actually, the localized corrosion that occurred in the chloride + chromate solution is what would be expected at $\mathrm{OCP}$ in $0.5 \mathrm{M} \mathrm{NaCl}$ solution.

The addition of dilute dichromate to the electrolyte provided an added cathodic reactant. The reduction of dichromate allowed the rate of $\mathrm{Al}$ dissolution following depassivation by scratching with the AFM tip to be sustained above a critical level, thereby promoting pit stability. Under these conditions, this dilute dichromate concentration accelerated and stabilized pitting instead of preventing it. The dichromate reduction product apparently had no beneficial influence. The reduction of dichromate alone is insufficient to inhibit localized corrosion. Interestingly, the addition of dichromate to chloride solutions also has been found to have no effect on the dissolution kinetics of $\mathrm{Al}$ artificial pit electrodes, even though the dichromate was definitely reduced at the electrode surface. ${ }^{37}$ On the other hand, Cinderey et al. monitored the potential increase after the guillotining of an $\mathrm{Al}$ electrode and attributed the faster potential increase observed in chromate-containing solutions to accelerated repassivation. ${ }^{12}$ 

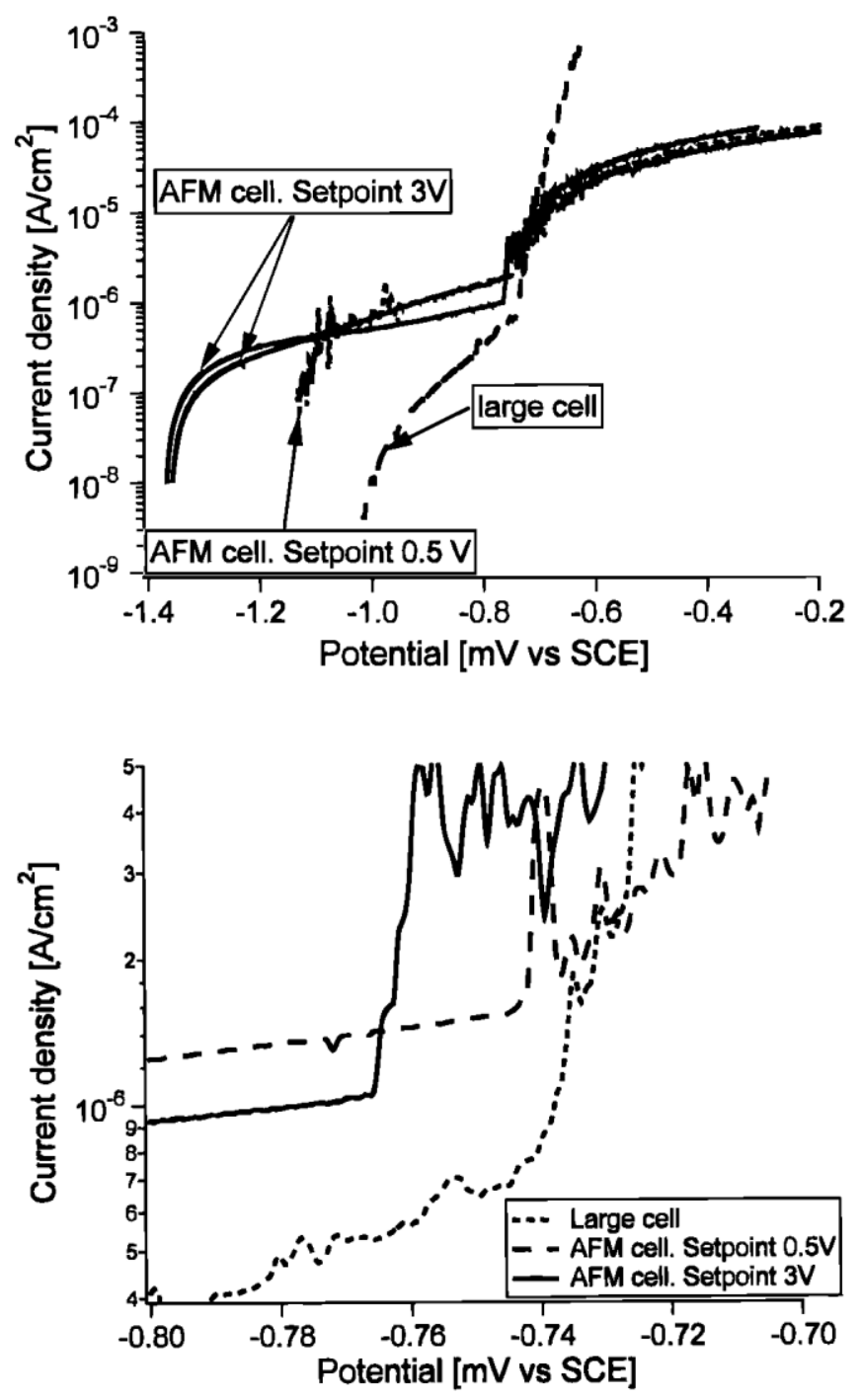

Figure 5. (a, top) Anodic polarization curves for $\mathrm{Al} 99.99 \%$ in $0.5 \mathrm{M} \mathrm{NaCl}$ for different setups. Scratching was started at the initiation of the potential scan for the samples tested in the AFM. (b, bottom) Expanded view of the region near the pitting potential for the different conditions.

Whereas these experiments showed how dichromate ions can actually stimulate localized corrosion during AFM scratching, the role of dichromate ions on the surface is complex and evidence for inhibiting effects has been found with this technique. A sample immersed for $3 \mathrm{~h}$ in the same $0.5 \mathrm{M} \mathrm{NaCl}+10^{-4} \mathrm{M} \mathrm{Na}_{2} \mathrm{Cr}_{2} \mathrm{O}_{7}$ solution before starting the scratching did not show the localized breakdown behavior upon scratching. It also did not form a deep smooth-bottomed trough with increasing set point as in the case of $0.5 \mathrm{M} \mathrm{NaCl}$ solution. In fact, scratching even at high-force set points hardly changed the surface at all in this case. Aging in this dilute dichromate/chloride solution apparently alters the surface layer. The formation of $\mathrm{Cr}$ (III) 

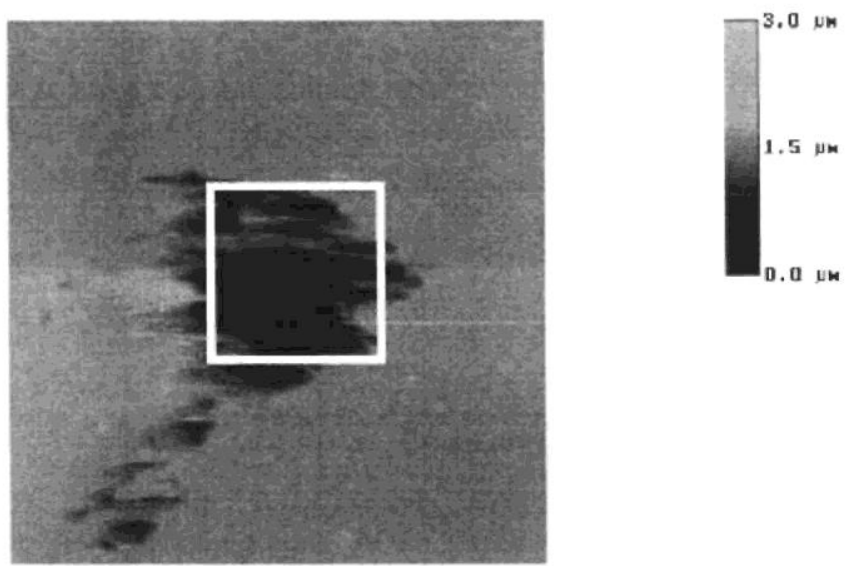

0

$50 \mathrm{um}$

\section{Height}

\section{$Z$ range: 3 um}
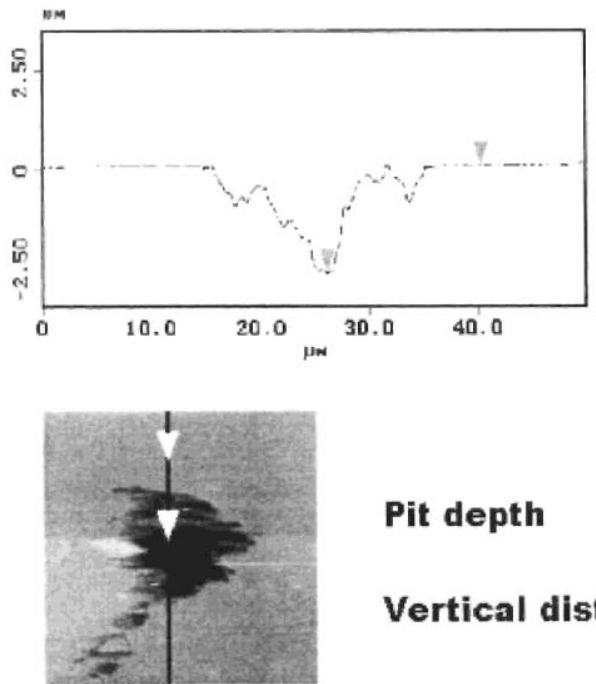

Pit depth

Vertical distance: 2.7 um

Figure 6. (a, top) In situ topographic map of a pit in Al 99.99\% obtained by contact mode scratching at a set point of $1 \mathrm{~V}$ in $0.5 \mathrm{M} \mathrm{NaCl}+10^{-4} \mathrm{M} \mathrm{Na} 2 \mathrm{Cr}_{2} \mathrm{O}_{7}$. The box indicates the scratched area. (b, bottom) Topography linescan across the pit. 


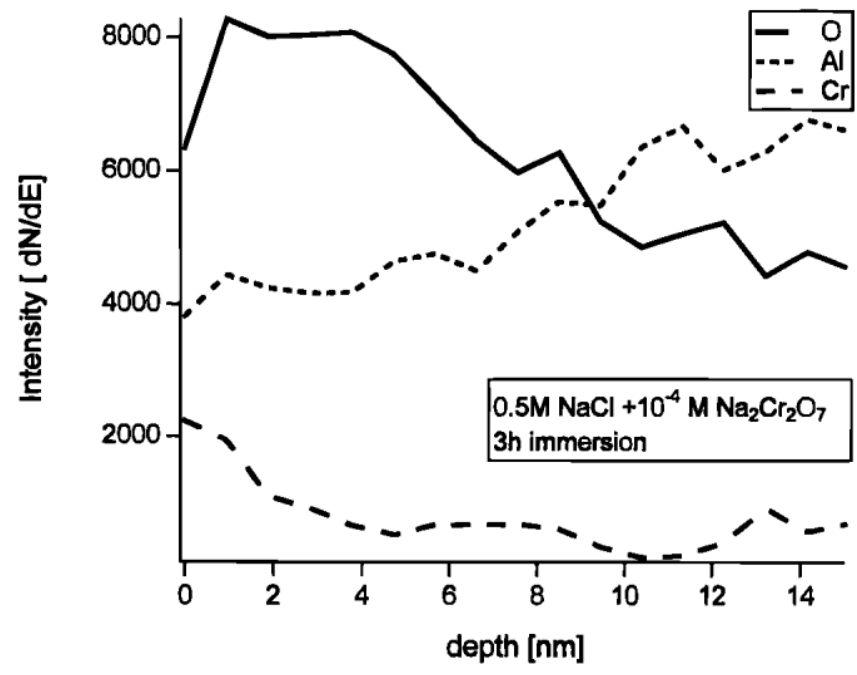

Figure 7. Auger depth profile of pure aluminum after immersion in $0.5 \mathrm{M} \mathrm{NaCl}+10^{-4} \mathrm{M} \mathrm{Na}_{2} \mathrm{Cr}_{2} \mathrm{O}_{7}$ for $3 \mathrm{~h}$.

oxy-hydroxide by reduction of $\mathrm{Cr}(\mathrm{VI})$ is likely to result in a stronger or harder film with time. Evidence of the formation of a strong, more tenacious surface film on Al in the presence of higher concentrations of dichromate was found with thin-film pitting experiments. ${ }^{31}$ As a $2 \mathrm{D}$ pit grew in the Al thin film, the undermined passive layer was observed to remain in place instead of being lifted off the surface by hydrogen bubbles. An Auger depth profile of a sample exposed for $3 \mathrm{~h}$ to this dilute dichromate concentration shows that the external part of the oxy-hydroxide film contained a significant amount of chromium, Fig. 7.

Similar experiments were performed in solutions with higher dichromate ion concentrations. In $0.5 \mathrm{M} \mathrm{NaCl}+0.05 \mathrm{M} \mathrm{Na}_{2} \mathrm{Cr}_{2} \mathrm{O}_{7}$ the sample did not change significantly during scratching. Figure 8 a shows the first scan, which was begun immediately after immersion, and Fig. $8 \mathrm{~b}$ shows the surface after rastering for up to $6 \mathrm{~h}$ with force set point increasing to $5 \mathrm{~V}$. The rastered area is visible in the center of the image. Debris is lined up in the direction of rastering and is piled at the edge of the rastered area. The depth of the rastered area relative to the unrastered area is on the order of the resolution of the instrument, 1-2 nm. This effect is similar to that observed for the sample scratched after aging for $3 \mathrm{~h}$ in $0.5 \mathrm{M} \mathrm{NaCl}+10^{-4} \mathrm{M} \mathrm{Na}_{2} \mathrm{Cr}_{2} \mathrm{O}_{7}$. The larger dichromate concentration should provide more oxidizing power. However, the absence of localized breakdown is a result of the ability of dichromate to reduce and form a hard surface film that could not be scratched away with the AFM tip. At high dichromate concentrations, this film formation dominates any deleterious effect of increased oxidizing power. The lack of pitting even at high applied set points in these experiments may be a result of damage to the tip during scratching at the lower set points. 
Table I. Summary of the observed corrosion behavior of pure Al, AA2024-T3, and pure Mg for different experiment conditions and solutions.

\begin{tabular}{|c|c|c|c|}
\hline Solution & $\mathrm{Al}(99.99 \%$ pure $)$ & AA2024-T3 & $\mathrm{Mg}$ \\
\hline $0.5 \mathrm{M} \mathrm{NaCl}$ & Smooth trough & $\begin{array}{l}\text { Pits at } S \text { phase } \\
\left(0.01 \mathrm{M} \mathrm{Cl}^{-}\right)\end{array}$ & \\
\hline $\begin{array}{l}0.5 \mathrm{M} \mathrm{NaCl}+10^{-4} \mathrm{M} \\
\mathrm{Na}_{2} \mathrm{Cr}_{2} \mathrm{O}_{7} \\
\text { immediate }\end{array}$ & Pits at a set point of $1 \mathrm{~V}$ & $\begin{array}{l}\text { Pits in the matrix at } \\
\text { a set point of } 0.5 \mathrm{~V}\end{array}$ & \\
\hline $\begin{array}{l}0.5 \mathrm{M} \mathrm{NaCl} \\
\text { solution flow }\end{array}$ & Pits at a set point of $0.5 \mathrm{~V}$ & & \\
\hline $\begin{array}{l}\text { Dearated } 0.5 \mathrm{M} \mathrm{NaCl} \\
\text { solution flow }\end{array}$ & Smooth trough & & \\
\hline $\begin{array}{l}0.5 \mathrm{M} \mathrm{NaCl}+10^{-4} \mathrm{M} \\
\mathrm{Na}_{2} \mathrm{Cr}_{2} \mathrm{O}_{7} \\
3 \text { h delay }\end{array}$ & $\begin{array}{l}\text { Nothing at low set point } \\
\text { (no trough or pits). } \\
\text { Pits at } 2-3 \mathrm{~V} \text { set point }\end{array}$ & & \\
\hline $\begin{array}{l}0.5 \mathrm{M} \mathrm{NaCl}+0.005 \mathrm{M} \\
\mathrm{Na}_{2} \mathrm{Cr}_{2} \mathrm{O}_{7} \\
\text { immediate }\end{array}$ & $\begin{array}{l}\text { Nothing at low set point. } \\
\text { Pits at } 3 \mathrm{~V} \text { set point }\end{array}$ & $\begin{array}{l}\text { Pits at } S \text { phase at } \\
\text { a set point of } 3 \mathrm{~V} \text {. }\end{array}$ & \\
\hline $\begin{array}{l}0.5 \mathrm{M} \mathrm{NaCl}+0.05 \mathrm{M} \\
\mathrm{Na}_{2} \mathrm{Cr}_{2} \mathrm{O}_{7} \\
\text { immediate }\end{array}$ & Nothing & $\begin{array}{l}\text { Pits at } S \text { phase at a } \\
\text { set point of } 3 \mathrm{~V}\end{array}$ & \\
\hline $\begin{array}{l}\text { DI } \mathrm{H}_{2} \mathrm{O} \\
10^{-4} \mathrm{M} \mathrm{Na}_{2} \mathrm{Cr}_{2} \mathrm{O}_{7}\end{array}$ & Nothing & Nothing & $\begin{array}{l}\text { Pits at } 0.5 \mathrm{~V} \text { set point } \\
\text { Pits at } 7 \mathrm{~V} \text { set point }\end{array}$ \\
\hline
\end{tabular}

A

B

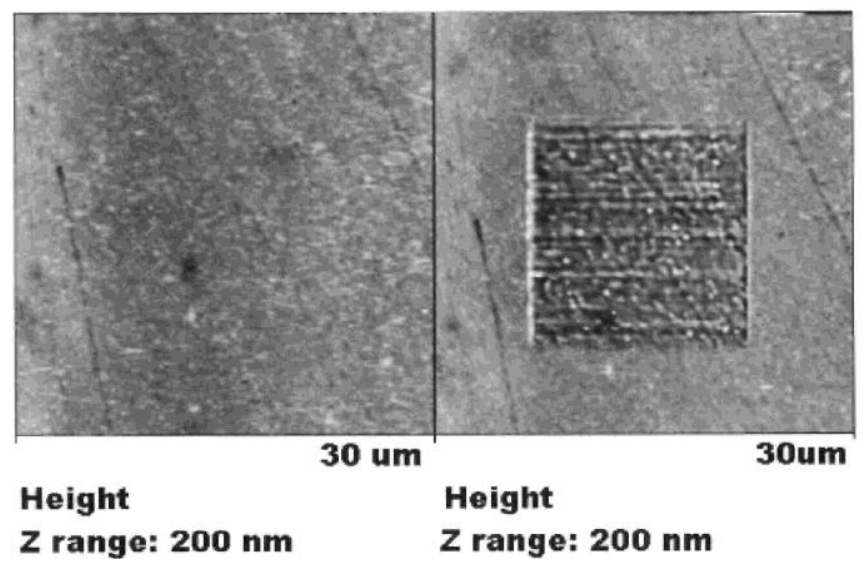

Figure 8. In situ topographic map in $\mathrm{Al} 99.99 \%$ obtained by contact-mode scratching in $0.5 \mathrm{M} \mathrm{NaCl}+0.05 \mathrm{M}$ $\mathrm{Na} 2 \mathrm{Cr}_{2} \mathrm{O}_{7}$ : (a) first scan at $0.2 \mathrm{~V}$ set point and (b) after scratching the central $15 \times 15 \mu \mathrm{m}$ square region at increasing set point voltages up to $5 \mathrm{~V}$ by $1 \mathrm{~V} / \mathrm{h}$ steps.

Table I summarizes the different observations for the different test conditions. The solution with intermediate dichromate concentration, $0.5 \mathrm{M} \mathrm{NaCl}+0.005 \mathrm{Na}_{2} \mathrm{Cr}_{2} \mathrm{O}_{7}$, also exhibited an intermediate behavior with a localized breakdown occurring but at a higher applied set point (higher applied force). This is an indication that there is a competition between the tendency of dichromate ion to accelerate corrosion by acting as an oxidizing agent and the tendency to form a protective film that inhibits corrosion. 


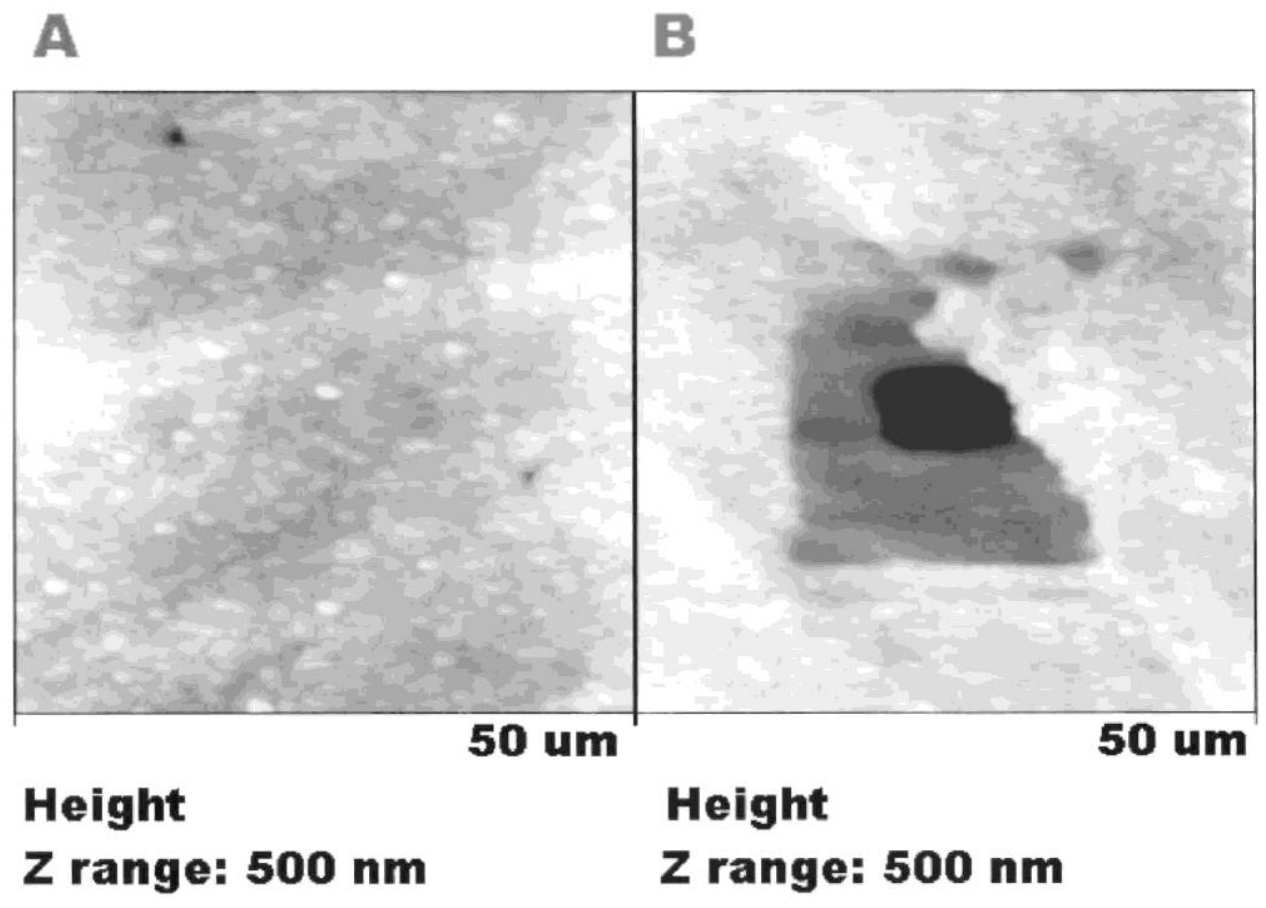

Figure 9. In situ topographic map of a hole in pure $\mathrm{Mg}(99.99 \%)$ obtained by contact-mode scratching of the central region in DI water: (a) first scan at $0.2 \mathrm{~V}$ set point and (b) after $1 \mathrm{~h}$ scratching at a set point of $0.5 \mathrm{~V}$.

Scratching of $M g$. - Since $\mathrm{Mg}$ is an important alloying element in AA2024-T3 and plays a significant role in the corrosion of the alloy, pure $\mathrm{Mg}$ was also investigated. $\mathrm{Mg}$ is not even stable during AFM scratching in deionized (DI) water. Figure 9 shows AFM images taken immediately upon immersion in water and after rastering at $0.5 \mathrm{~V}$ set point. After AFM rastering, the surface film was partly removed and localized breakdown occurred in the center of the image. The fact that localized dissolution was easily induced during scratching in ultrapure water indicates how difficult it is to polish an alloy such as AA2024-T3, which contains Mg-rich intermetallic particles. Adding $10^{-4} \mathrm{M} \mathrm{Na}_{2} \mathrm{Cr}_{2} \mathrm{O}_{7}$ in DI water decreased the tendency for pitting. There was still a localized breakdown, but a higher set point was required $(7 \mathrm{~V})$. Dichromate definitively has a protective effect for pure $\mathrm{Mg}$. Other authors reported the effect of chromate on stabilizing the $\mathrm{Mg}(\mathrm{OH})_{2}$ surface layer. ${ }^{33,34}$ 


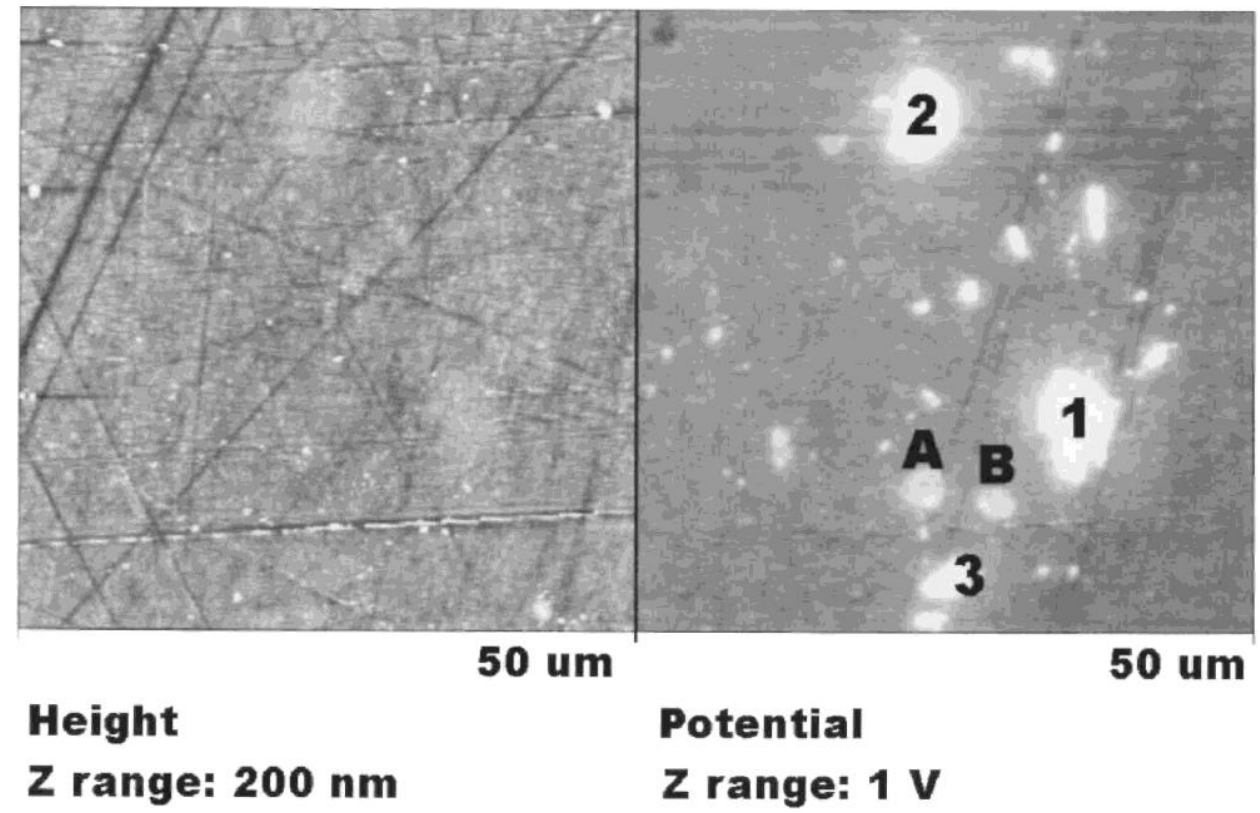

Figure 10. Topography (left) and SKPFM Volta potential map (right) of an as-polished AA2024-T3 alloy surface.

AFM Scratching of AA2024-T3.- It was possible to scratch an area of AA2024-T3 containing specific intermetallic particles. The location of the intermetallic particles was made clear from the Volta potential maps generated by SKPFM. As described in a previous paper, the different intermetallic particles behave differently during AFM scratching. ${ }^{27}$ In $0.01 \mathrm{M} \mathrm{NaCl}$, the $\mathrm{Al}-\mathrm{Cu}-(\mathrm{Fe}, \mathrm{Mn})$ particles etched slowly during rastering over long times, whereas $\mathrm{Al}-\mathrm{Cu}-\mathrm{Mg}$ particles dissolved immediately after the first raster scan of the surface. During simple immersion in $0.5 \mathrm{M} \mathrm{NaCl}$, small pits developed inside some of the $\mathrm{Al}-\mathrm{Cu}-(\mathrm{Fe}, \mathrm{Mn})$ particles and a trench formed around them in the surrounding matrix.

The addition of dichromate resulted in completely different behavior. Figure 10 shows the topography and Volta potential maps of an area of as-polished AA2024-T3 prior to the experiment. The bright areas in the Volta potential map on the right side indicate high potentials associated with the presence of intermetallic particles. ${ }^{27}$ The region contains both large Al-Cu(Fe, $\mathrm{Mn}$ ) (the largest particles are labeled 1-3) and $\mathrm{Al}-\mathrm{Cu}-\mathrm{Mg}$ particles (A and B). The Fe,Mncontaining particles are seen to have a higher potential than the $\mathrm{Mg}$-containing particles. Rastering in $0.5 \mathrm{M} \mathrm{NaCl}+10^{-4} \mathrm{M} \mathrm{Na}_{2} \mathrm{Cr}_{2} \mathrm{O}_{7}$ for $6 \mathrm{~h}$ without solution flow at a set point of $0.5 \mathrm{~V}$ left the $\mathrm{Al}-\mathrm{Cu}-\mathrm{Mg}$ particle uncorroded, as observed on the topographic map on the left side of Fig. 11. Interestingly, localized breakdown occurred in this case in the matrix away from the intermetallic particles. This behavior can be related to the fact that pure aluminum also exhibits pitting in this condition. The potential of the Al-Cu-Mg particles is still slightly higher than that of the matrix, and they are barely visible in the Volta potential map. The large Al-Cu-(Fe, $\mathrm{Mn})$ particles can still be clearly seen in the potential map. A very interesting feature can also be observed. A cell-like high-potential structure appeared in the scratched region. This structure formed near the $\mathrm{Al}-\mathrm{Cu}-(\mathrm{Fe}, \mathrm{Mn})$ particles and was also connected to the corroded area which also shows higher potential. Auger spectroscopy was used to analyze this sample. No significant difference in composition was observed at the cell-like area relative to the matrix region that did 
not exhibit potential contrast.

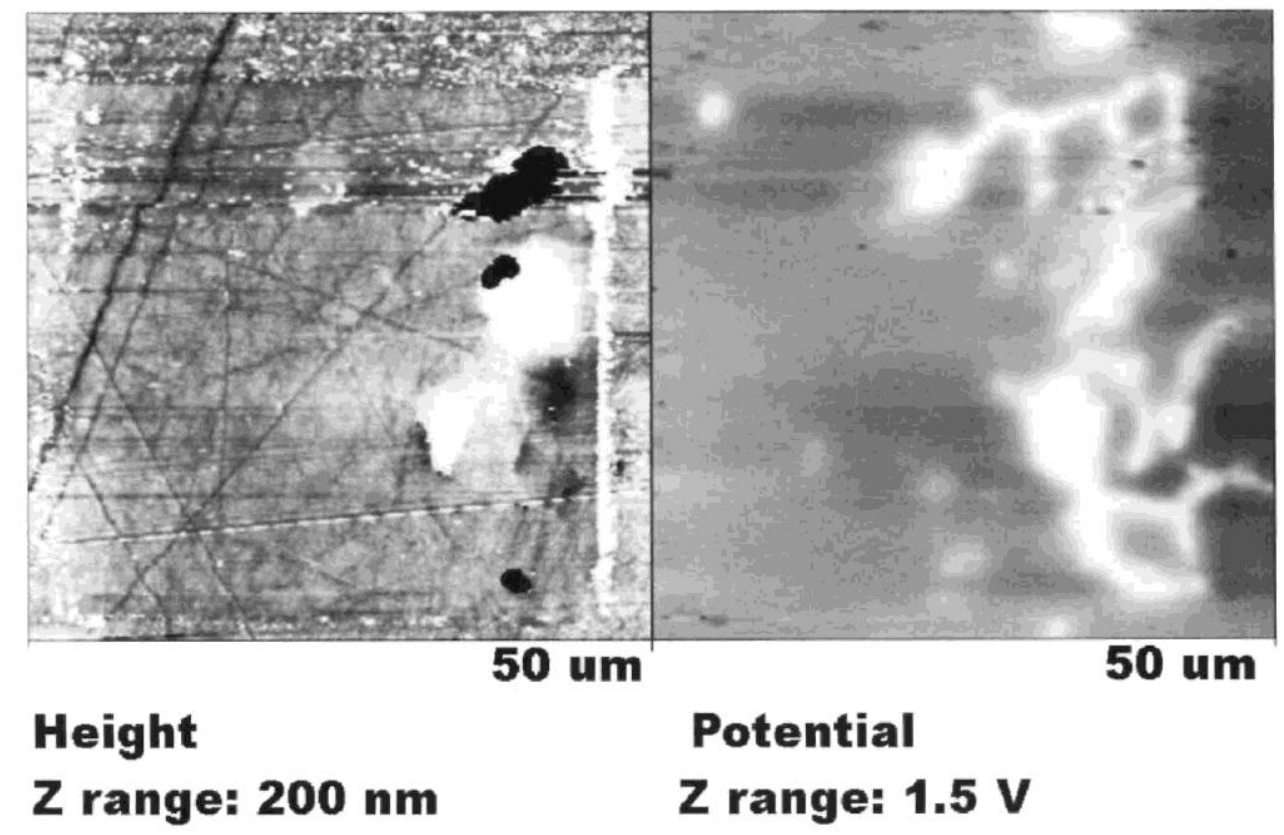

Figure 11. Topography (left) and SKPFM Volta potential map (right) of the AA2024-T3 alloy surface after contactmode scratching the central $45 \times 45 \mu \mathrm{m}$ square region in $0.5 \mathrm{M} \mathrm{NaCl}+10^{-4} \mathrm{M} \mathrm{Na}_{2} \mathrm{Cr}_{2} \mathrm{O}_{7}$ at $0.5 \mathrm{~V}$ set point for $6 \mathrm{~h}$.

A scanning electron microscopy (SEM) image of the same area, Fig. 12, indicates that part of the cell-like structure is associated with features having lower secondary electron emission. These features appear to be cracks on the surface, but the AFM topographic map shows no indication of cracks at these locations. SEM contrast can be generated by both surface topography and atomic mass differences, so one must be careful in interpreting SEM images. For instance, the large intermetallic particles appear to be sticking up far out of the surface, but the AFM image indicates that the large central particle is rather coplanar with the surface. Other particles, in particular the Al-Cu-Mg particles, may actually be depressed from the surface plane despite appearing bright in the SEM image. The high $\mathrm{Cu}$ content of these particles adds to the SEM contrast. Other features seen in the AFM topographic map are not visible in the SEM image. For instance, the rastered area is outlined in the AFM topographic map by debris left by the scratching process. Also, there is a large mound of corrosion product visible in the topographic map. These features are not seen in the SEM image, perhaps owing to their low atomic mass, which dominates the influence of the physical protrusion from the surface.

The size and shape of the cell-like potential structure and the associated SEM features suggest that they may be related to grain boundaries. Since they are not visible in the topographic map, they could be grain boundary cracks covered by a thin surface layer having low atomic mass. This surface layer may be a corrosion product, which may be smeared over the surface by the scratching. Potential contrast can be seen through a thin overlayer if there is no charge associated with that layer. For instance, there is no potential contrast associated with the line of debris described previously. In summary, the origin of both the SEM contrast and the potential 
contrast at these features is not clear. However, it should be mentioned that this type of cell-like potential structure was reproducibly observed on AA2024-T3 in this solution with $10^{-4} \mathrm{M}$ $\mathrm{Na}_{2} \mathrm{Cr}_{2} \mathrm{O}_{7}$.

Figure 13 shows topographic and potential maps for a region in another as-polished AA2024-T3 sample prior to testing. Different noble particles are visible. Particles A and B are $\mathrm{Al}-\mathrm{Cu}-\mathrm{Mg}$ intermetallics and the large central particle labeled 1 is $\mathrm{Al}-\mathrm{Cu}-(\mathrm{Fe}, \mathrm{Mn})$. This sample was rastered in a chloride solution with higher dichromate concentration, $0.5 \mathrm{M} \mathrm{NaCl}+0.005 \mathrm{M}$ $\mathrm{Na}_{2} \mathrm{Cr}_{2} \mathrm{O}_{7}$. No localized corrosion could be achieved at low applied set point in this case, so the applied force was increased gradually. Figure 14a shows the first scan in contact mode of the

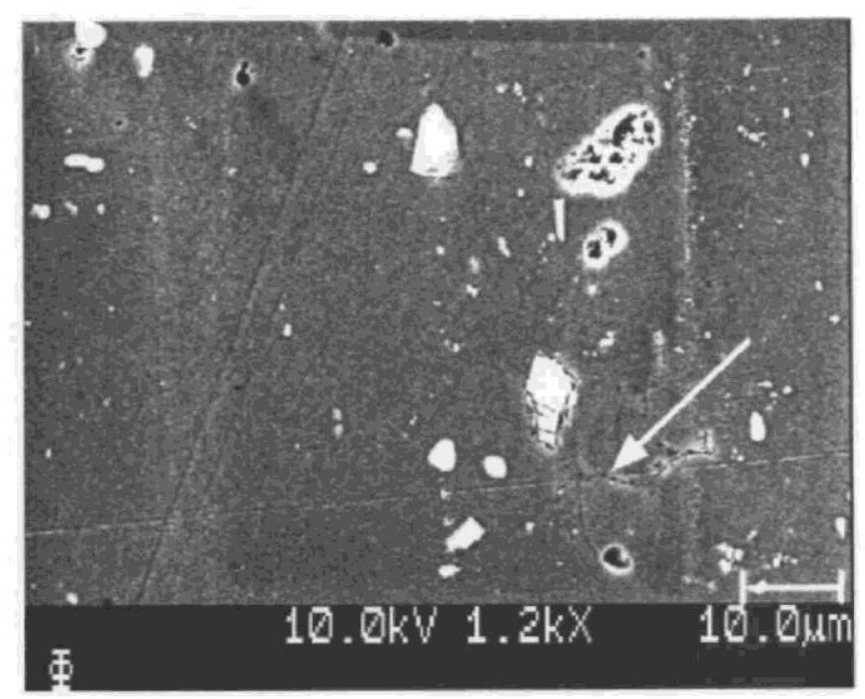

Figure 12. SEM image of the area shown in Fig. 11. 


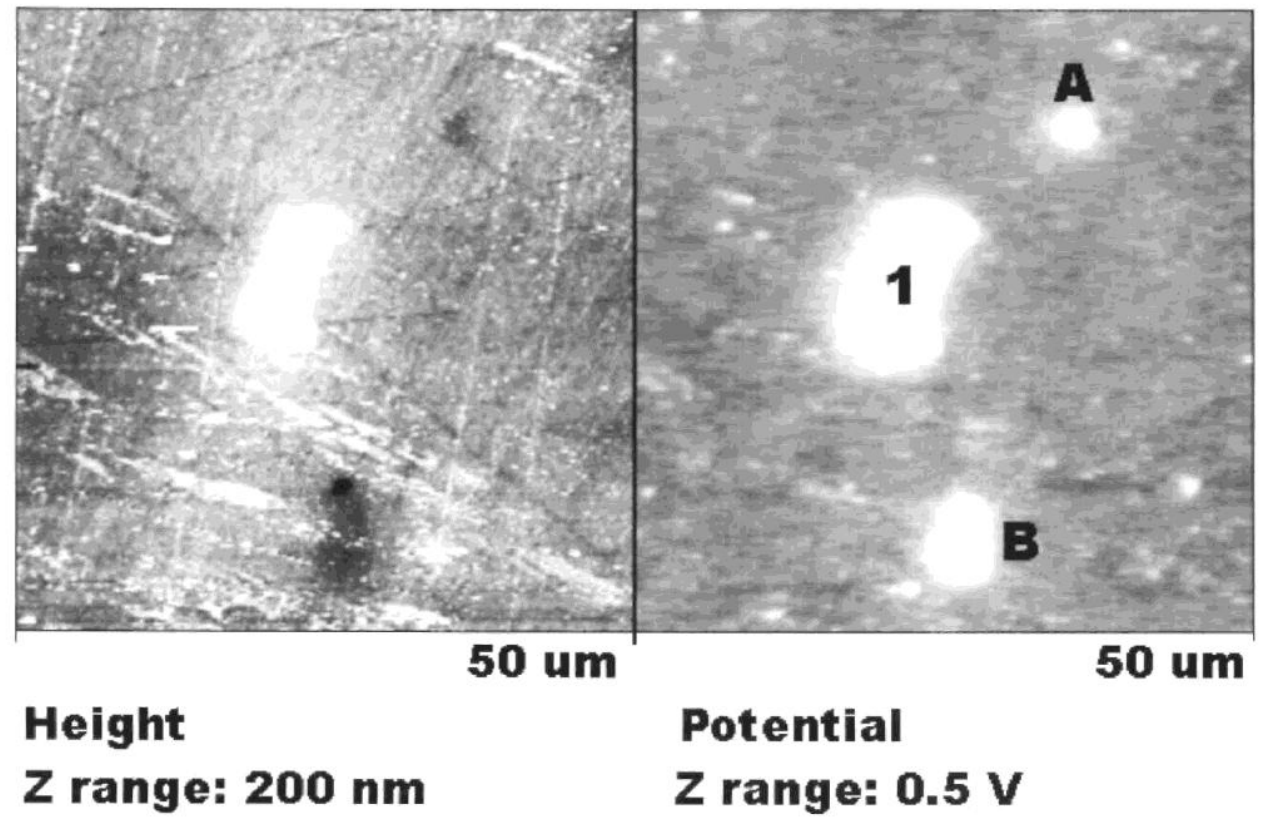

Figure 13. Topography (left) and SKPFM Volta potential map (right) of an as-polished AA2024-T3 alloy surface.

immersed sample. The Al-Cu-Mg particle can be distinguished by the slightly depressed region, and the central $\mathrm{Al}-\mathrm{Cu}-(\mathrm{Fe}, \mathrm{Mn})$ particle is sticking out of the surface. After $1 \mathrm{~h}$ of rastering at a set point of $1 \mathrm{~V}$ (Fig. 14b), the Al-Cu-Mg particles start to be covered with products. The products on particle A were removed by subsequent rastering at a $2 \mathrm{~V}$ set point for $1 \mathrm{~h}$ and the underlying surface was apparently unattacked, Fig. 15a. At a set point of $3 \mathrm{~V}$, localized breakdown occurred, this time starting at particle A and extending into the surrounding matrix, Fig. 15b. (The scanned region is slightly offset from that shown in Fig. 13.) Particle B did not dissolve but was covered with some products accumulated during the rastering at lower set points but were not scratched away with the AFM tip rastering even at high force.

Figure 16 shows an SKPFM image of the surface recorded in air after the scratching experiment. The portion of the pit where the $\mathrm{Al}-\mathrm{Cu}-\mathrm{Mg}$ particle had been located exhibits a high potential. Pits associated with particles have been found to typically exhibit high potentials. ${ }^{26}$ Auger analysis indicated that the entire surface contained some $\mathrm{Cr}$ after this exposure, which is the same as was found for pure aluminum (Fig. 7). However, no lateral distribution that could account for this potential contrast was observed. 


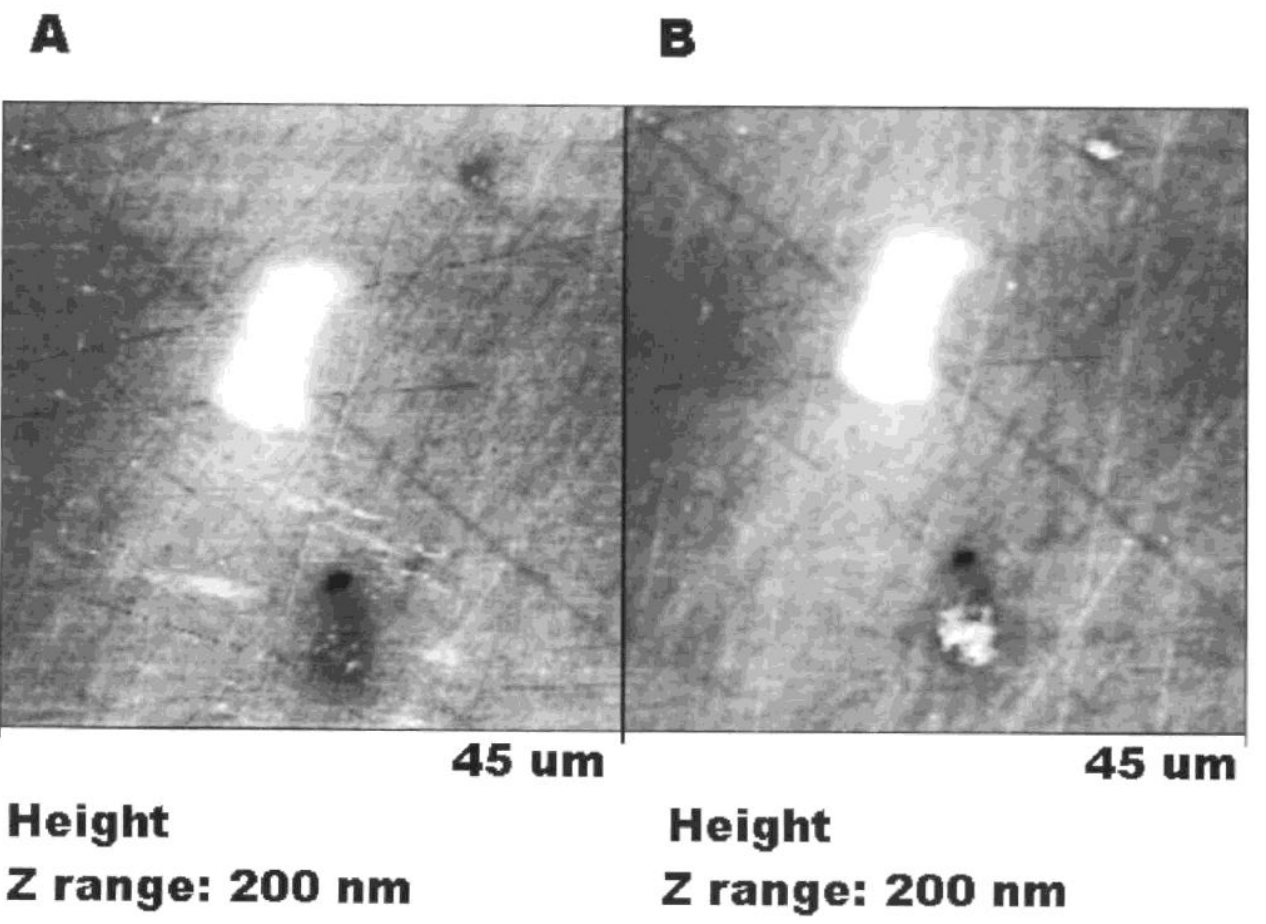

Figure 14. In situ topographic map of the AA2024-T3 alloy obtained by contact-mode scratching in $0.5 \mathrm{M} \mathrm{NaCl}+$ $0.005 \mathrm{M} \mathrm{Na}_{2} \mathrm{Cr}_{2} \mathrm{O}_{7}$ : (a) first scan at $0.2 \mathrm{~V}$ set point and (b) after $1 \mathrm{~h}$ scratching the whole area at $1 \mathrm{~V}$ set point.

Scratching in a solution with yet-higher dichromate concentration, $0.5 \mathrm{M} \mathrm{NaCl}+0.05 \mathrm{M}$ $\mathrm{Na}_{2} \mathrm{Cr}_{2} \mathrm{O}_{7}$, still resulted in attack at an $\mathrm{Al}-\mathrm{Cu}-\mathrm{Mg}$ particle as can be seen by comparing the potential map of Fig. 17, recorded before immersion and the same area after the scratching experiment, Fig. 18. Pitting started at the same set point of $3 \mathrm{~V}$ as for the $0.5 \mathrm{M} \mathrm{NaCl}+0.005 \mathrm{M}$ $\mathrm{Na}_{2} \mathrm{Cr}_{2} \mathrm{O}_{7}$ solution, but the amount of dissolution is much smaller and it did not spread laterally. Since the extent of dissolution was so small, scratching was continued after pitting started for this sample to investigate the behavior at higher set points. Figure 18 shows the sample after scratching at $5 \mathrm{~V}$. The very small extent of attack suggests that this higher amount of dichromate might improve the repassivation ability of the $\mathrm{Al}-\mathrm{Cu}-\mathrm{Mg}$ particles or the matrix. Before this localized attack occurred, these $\mathrm{Al}-\mathrm{Cu}-\mathrm{Mg}$ particles were seen to be covered with products during the scan at a set point of $1 \mathrm{~V}$ the same way as in the $0.5 \mathrm{M} \mathrm{NaCl}+0.005 \mathrm{M} \mathrm{Na}_{2} \mathrm{Cr}_{2} \mathrm{O}_{7}$. These products were also removed later at higher set point before the particles started to corrode. 


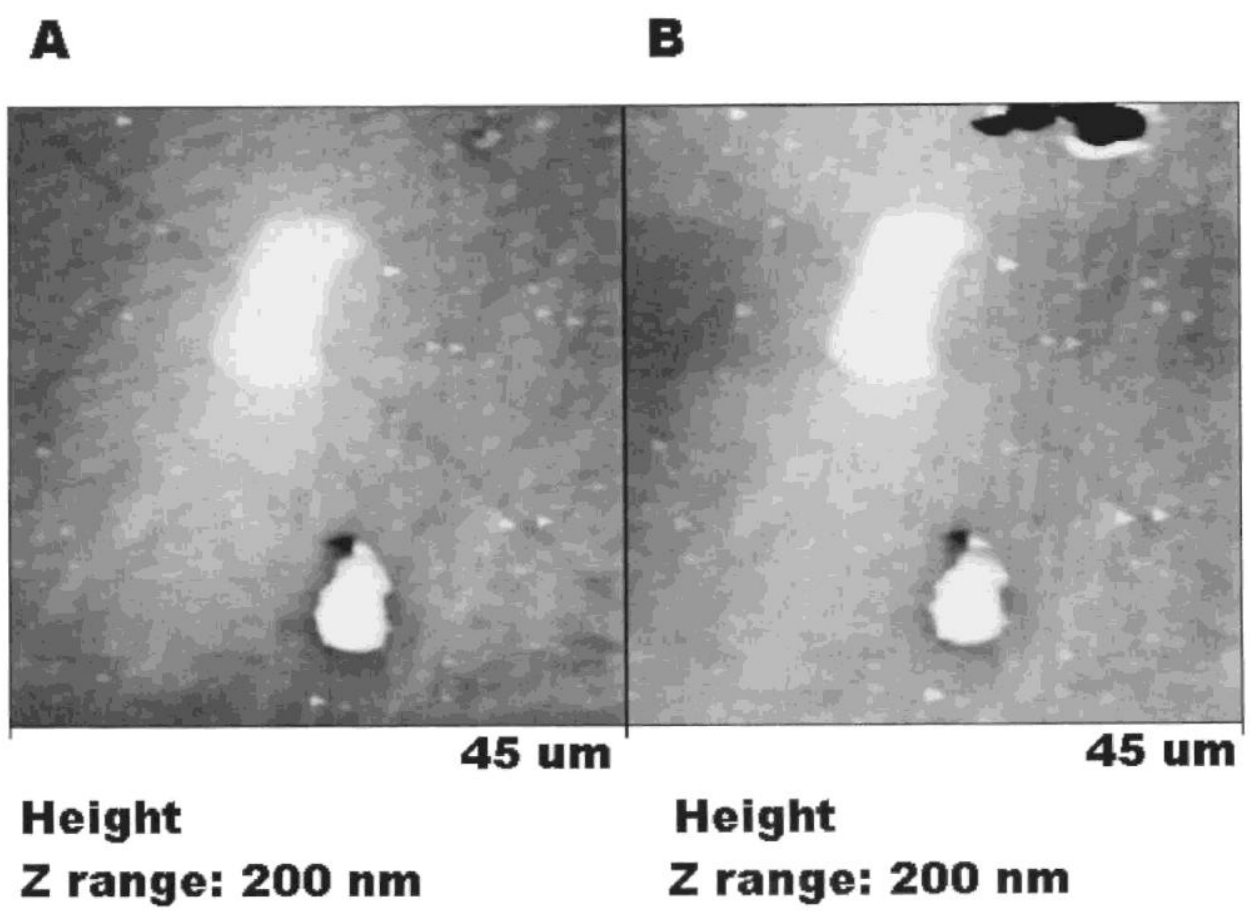

Figure 15. In situ topographic map of an AA2024-T3 alloy obtained by contact-mode scratching in $0.5 \mathrm{M} \mathrm{NaCl}+$ $0.005 \mathrm{M} \mathrm{Na}_{2} \mathrm{Cr}_{2} \mathrm{O}_{7}$ : (a) after $1 \mathrm{~h}$ scratching at $1 \mathrm{~V}$ set point followed by $1 \mathrm{~h}$ at $2 \mathrm{~V}$ set point and (b) breakdown observed at $3 \mathrm{~V}$ set point.

Auger analysis of these products on the $\mathrm{Al}-\mathrm{Cu}-\mathrm{Mg}$ particles indicates that they are enriched in $\mathrm{Cr}^{38}$ Since the particles under the product layers do not seem to be corroded, the products may be deposits from solution. Brown et al. suggested that the deposition of hydrated chromium occurs at locations where the passive film is more conducting or thinner, ${ }^{39}$ which might be the case on the Mg-containing intermetallic particles. It is interesting that no deposit was observed on the Al-Cu-Mg particles for low dichromate concentration, Fig. 11. On the other hand, one of the large $\mathrm{Al}-\mathrm{Cu}-(\mathrm{Fe}, \mathrm{Mn})$ particles was partially covered with products. In any case, no corrosion was related to this deposition process and the specific deposition location changed from one type of intermetallic particle to the other as the concentration of dichromate ions in solution changed. 


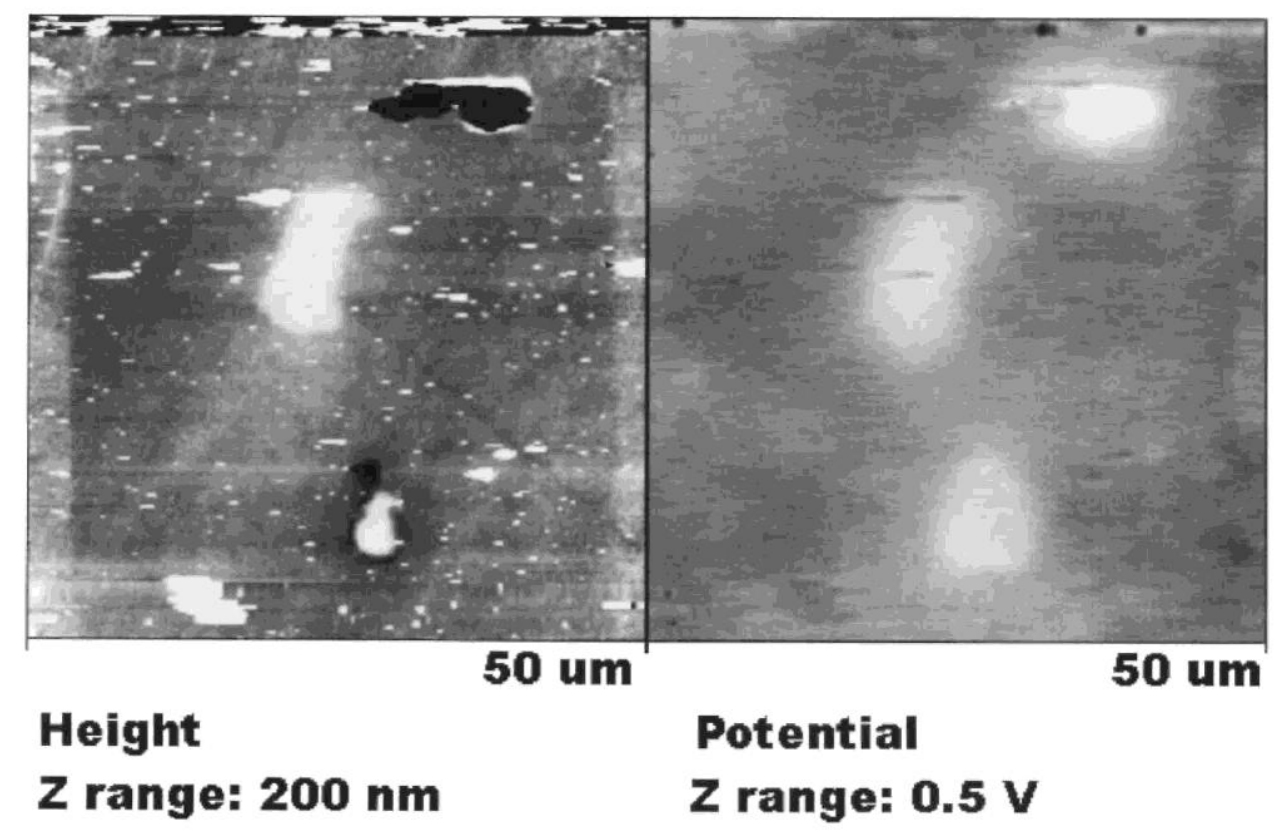

Figure 16. Topography and SKPFM Volta potential maps of sample of Fig. 13 after scratching experiment.

The absence of corrosion for $\mathrm{Al}-\mathrm{Cu}-\mathrm{Mg}$ particles in the solution containing dilute dichromate $\left(0.5 \mathrm{M} \mathrm{NaCl}+10^{-4} \mathrm{M} \mathrm{Na}_{2} \mathrm{Cr}_{2} \mathrm{O}_{7}\right)$ may be related to the observation described above where pure $\mathrm{Mg}$ was protected from corrosion in chloride free $10^{-4} \mathrm{M} \mathrm{Na}_{2} \mathrm{Cr}_{2} \mathrm{O}_{7}$ by the formation of a surface layer. Breaking of that layer by the application of a high tip pressure resulted in rapid corrosion of the $\mathrm{Mg}$, and similar rapid corrosion of the $\mathrm{Al}-\mathrm{Cu}-\mathrm{Mg}$ particle in $0.5 \mathrm{M} \mathrm{NaCl}+$ $0.005 \mathrm{M} \mathrm{Na}_{2} \mathrm{Cr}_{2} \mathrm{O}_{7}$ is found when the pressure is increased. In the case of $0.5 \mathrm{M} \mathrm{NaCl}+10^{-4} \mathrm{M}$ $\mathrm{Na}_{2} \mathrm{Cr}_{2} \mathrm{O}_{7}$, corrosion of AA2024-T3 occurred at a very low set point in the matrix, so that the corrosion behavior of the $\mathrm{Al}-\mathrm{Cu}-\mathrm{Mg}$ could not be studied separately. 


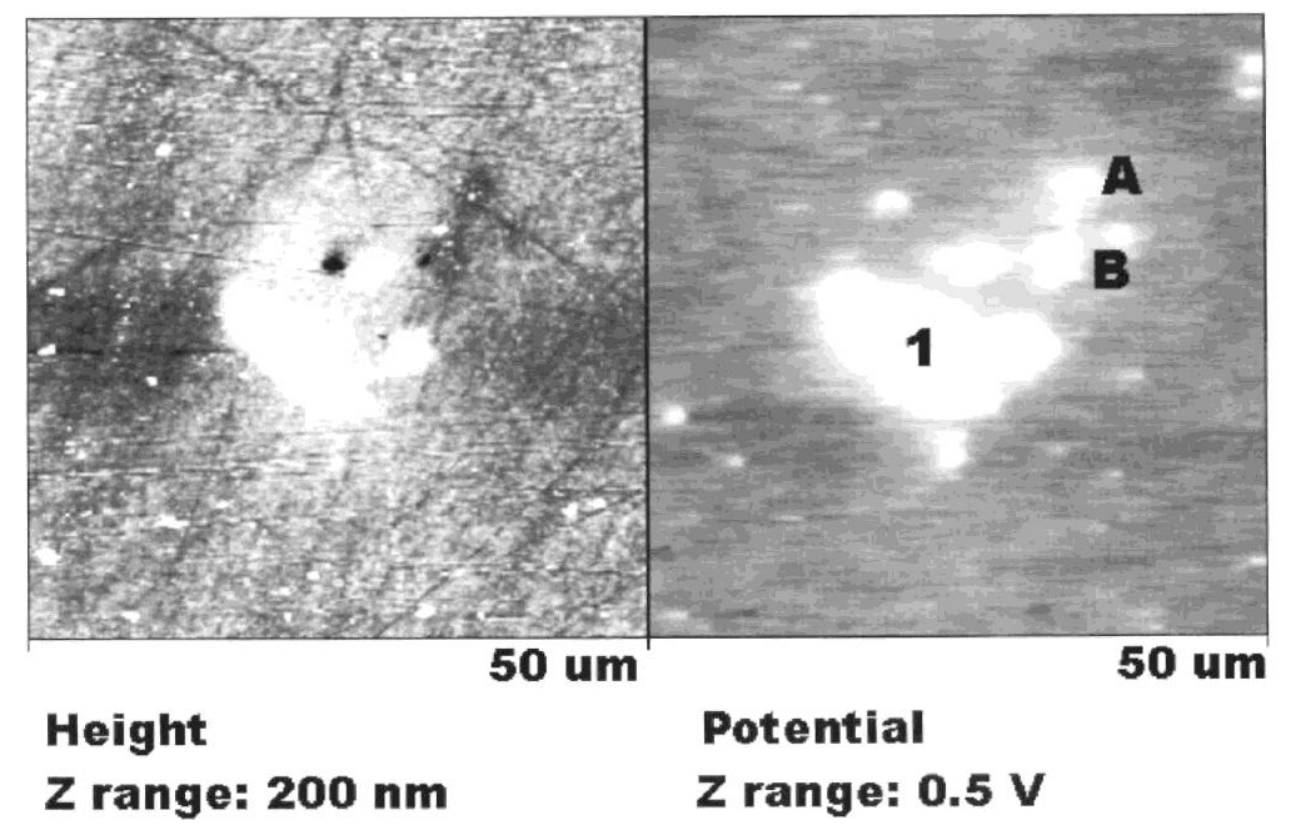

Figure 17. Topography (left) and SKPFM Volta potential map (right) of an as-polished AA2024-T3 alloy surface.

\section{Conclusions}

AFM was used to study the corrosion of pure aluminum and AA 2024-T3 by providing topographic maps of accelerated dissolution obtained via local in situ scratching of the surface. The following observations were made

1. The dissolution rate of pure $\mathrm{Al}$ in $0.5 \mathrm{M} \mathrm{NaCl}$ was found to be accelerated by rastering of the AFM tip across the surface, resulting in the formation of a deep, flat-bottomed trench. 2. Pumping of the electrolyte through the AFM cell or addition of a small concentration of dichromate ions (10-4 M) completely changed the corrosion behavior of Al, resulting in deep localized attack. The localized corrosion occurred because of the addition of extra cathodic reactant, either dichromate (if dilute) or oxygen.

3. In the presence of higher dichromate concentrations ( $0.005 \mathrm{M}$ and more), neither trenching nor localized attack was possible. AFM scratching had almost no effect on the sample surface, perhaps owing to the formation of a harder film.

4. Different polishing procedures resulted in different behavior for pure Al. Even with solution flow, the lower OCP obtained for diamond-polished samples prevented the pitting phenomenon observed for samples polished with colloidal silica.

5. For the AA2024-T3 alloy, addition of $10^{-4} \mathrm{M}$ dichromate in $0.5 \mathrm{M} \mathrm{NaCl}$ was sufficient to protect the $\mathrm{Al}-\mathrm{Cu}-\mathrm{Mg}$ particles that immediately dissolved upon rastering in pure $\mathrm{NaCl}$ solutions. On the other hand, localized breakdown occurred in the matrix.

6. In the presence of higher amounts of dichromate $(0.005$ or $0.05 \mathrm{M})$ in $0.5 \mathrm{M} \mathrm{NaCl}$, higher applied tip forces were needed to cause localized attack, which took place at the $\mathrm{Al}-\mathrm{Cu}-$ Mg particles. 


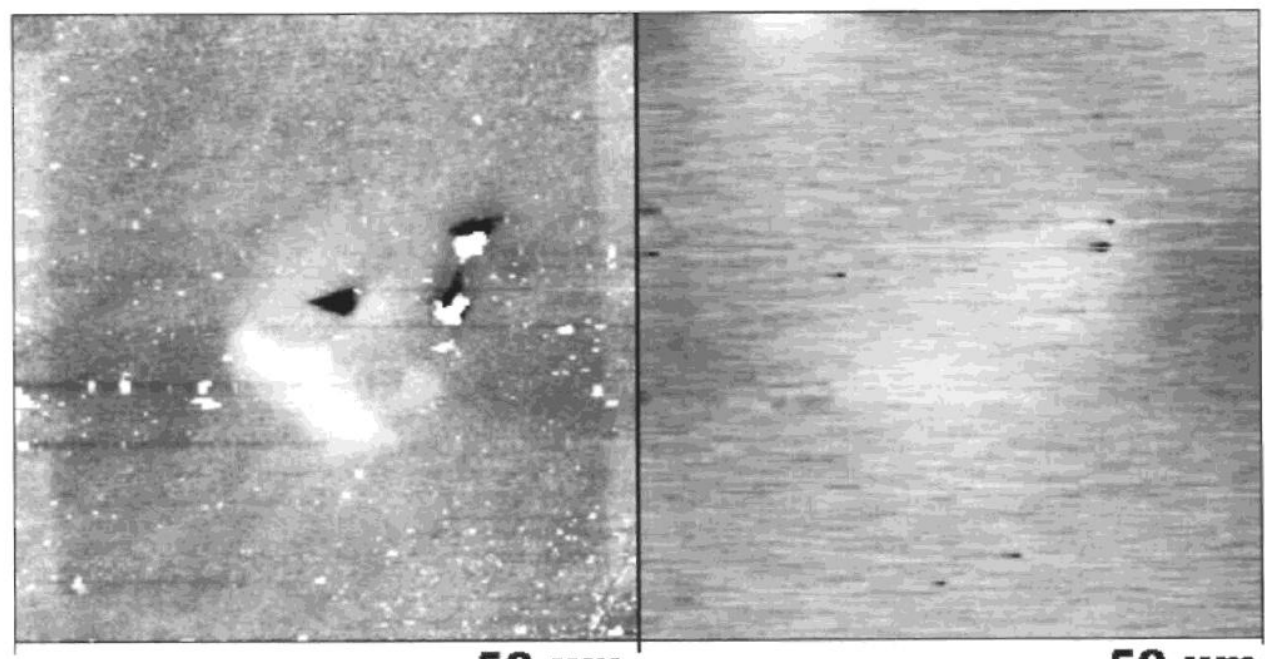

50 um

\section{Height $Z$ range: $200 \mathrm{~nm} \quad Z$ range: $0.2 \mathrm{~V}$}

Figure 18. Topography and SKPFM Volta potential maps obtained after contact-mode scratching the central $45 \times$ $45 \mu \mathrm{m}$ square region in $0.5 \mathrm{M} \mathrm{NaCl}+0.05 \mathrm{M} \mathrm{Na}_{2} \mathrm{Cr}_{2} \mathrm{O}_{7}$ up to $5 \mathrm{~V}$ set point in steps of $1 \mathrm{~V} / \mathrm{h}$.

\section{Acknowledgments}

This work was supported by Major H. DeLong in the Air Force Office of Scientific Research under contract F49620-96-1-0479. M. Kendig, S. L. Jeanjacquet, W. Schmidt, M. Stratmann, R. Buchheit, and T. Moffat are gratefully acknowledged for providing samples and for interesting discussions.

The Ohio State University assisted in meeting the publication costs of this article.

\section{References}

1. G. T. Burstein and G. Gao, J. Electrochem. Soc., 138, 2627 (1991).

2. R. D. K. Misra and G. T. Burstein, Corros. Sci., 24, 305 (1984).

3. G. T. Burstein and R. C. Newman, J. Electrochem Soc., 128, 2270 (1981).

4. G. T. Burstein and P. I. Marshall, Corros. Sci., 23, 125 (1983).

5. G. T. Burstein and R. C. Newman, Electrochim. Acta, 25, 1009 (1980).

6. F. P. Ford, G. T. Burstein, and T. P. Hoar, J. Electrochem. Soc., 127, 1325 (1980).

7. G. S. Frankel, C. V. Jahnes, V. Brusic, and A. J. Davenport, J. Electrochem. Soc., 142, 2290 (1995).

8. G. S. Frankel, B. M. Rush, C. V. Jahnes, and C. E. Farrell, J. Electrochem. Soc., 138, 643 (1991).

9. G. T. Burstein and R. J. Cinderey, Corros. Sci., 32, 1195 (1991).

10. G. T. Burstein and C. Liu, Electrochim. Acta, 39, 873 (1994).

11. R. J. Cinderey and G. T. Burstein, Corros. Sci., 33, 499 (1992).

12. R. J. Cinderey and G. T. Burstein, Corros. Sci., 33, 493 (1992).

13. G. T. Burstein and C. Liu, Corros. Sci., 37, 1151 (1995).

14. G. T. Burstein and R. J. Cinderey, Corros. Sci., 33, 475 (1992).

15. R. Oltra, C. Gabrielli, F. Huet, and M. Keddam, Electrochim. Acta, 31, 1501 (1986).

16. M. Itagaki, R. Oltra, B. Vuillemin, M. Keddam, and H. Takenouti, J. Electrochem. Soc., 144, 64 (1997).

17. R. Oltra, G. M. Indrianjafy, M. Keddam, and H. Takenouti, Corros. Sci., 35, 827 (1993). 
18. R. Oltra, G. M. Indrianjafy, and M. Keddam, Mater. Sci. Forum, 44-45, 259 (1989).

19. P. D. Bastek, R. C. Newman, and R. G. Kelly, J. Electrochem. Soc., 140, 1884 (1993).

20. H. J. Pearson, G. T. Burstein, and R. C. Newman, J. Electrochem. Soc., 128, 2297 (1981).

21. R. P. Wei, M. Gao, and P. Y. Xu, J. Electrochem. Soc., 136, 1835 (1989).

22. R. P. Wei and M. Gao, J. Electrochem. Soc., 138, 2601 (1991).

23. R. G. Kelly and R. C. Newman, J. Electrochem. Soc., 137, 357 (1990).

24. L. Chen and D. Guay, J. Electrochem. Soc., 141, L43 (1994).

25. L. Roue, L. Chen, and D. Guay, Langmuir, 12, 5818 (1996).

26. P. Schmutz and G. S. Frankel, J. Electrochem. Soc., 145, 2295 (1998).

27. P. Schmutz and G. S. Frankel, J. Electrochem. Soc., 145, 2285 (1998).

28. F. Hunkeler and H. Boehni, Corrosion, 37, 645 (1981).

29. H. Kaesche, in Localized Corrosion, Vol. 3, S. R. W. Staehle, B. F. Brown, J. Kruger, and A. Agrawal, Editors, p. 516, NACE, Houston, TX (1974).

30. S. T. Pride, J. R. Scully, and J. L. Hudson, J. Electrochem. Soc., 141, 3028 (1994).

31. A. Sehgal, D. Lu, and G. S. Frankel, J. Electrochem. Soc., 145, 2834 (1998).

32. H. J. Raetzer-Scheibe and C. D. S. Tuck, Corros. Sci., 36, 941 (1994).

33. I. J. Polmear, in Light Alloys: Metallurgy of the Light Metals, p. 214, Edward Arnold Publishers, Ltd., London (1981).

34. G. L. Makar, J. Kruger, and K. Sieradzki, J. Electrochem. Soc., 139, 47 (1992).

35. G. S. Frankel, J. R. Scully, and C. V. Jahnes, J. Electrochem. Soc., 143, 1834 (1996).

36. G. S. Frankel, R. C. Newmann, C. V. Jahnes, and M. A. Russak, J. Electrochem. Soc., 140, 2192 (1993).

37. E. Akiyama and G. S. Frankel, J. Electrochem. Soc., 146, 4095 (1999).

38. P. Schmutz and G. S. Frankel, J. Electrochem. Soc., To be submitted.

39. G. M. Brown, K. Shimizu, K. Kobayashi, G. E. Thompson, and G. C. Wood, Corros. Sci., 35, 253 (1993). 